University of Michigan Law School

University of Michigan Law School Scholarship Repository

\title{
Transfer Pricing Disputes in the United States
}

\section{Reuven S. Avi-Yonah}

University of Michigan Law School, aviyonah@umich.edu

Available at: https://repository.law.umich.edu/book_chapters/49

Follow this and additional works at: https://repository.law.umich.edu/book_chapters

Part of the Business Organizations Law Commons, Taxation-Federal Commons, and the Taxation-

Transnational Commons

\section{Publication Information \& Recommended Citation}

Avi-Yonah, Reuven S. "Transfer Pricing Disputes in the United States." In Resolving Transfer Pricing Disputes: A Global Analysis, edited by E. Baistrocchi and I. Roxan. New York: Cambridge Univ. Press, 2012.

This Book Chapter is brought to you for free and open access by the Faculty Scholarship at University of Michigan Law School Scholarship Repository. It has been accepted for inclusion in Book Chapters by an authorized administrator of University of Michigan Law School Scholarship Repository. For more information, please contact mlaw.repository@umich.edu. 


\title{
Transfer pricing disputes in the United States
}

\author{
REUVEN S. AVI-YONAH
}

\subsection{Introduction}

In 1988, the US Treasury Department published a study of inter-company pricing (the 'White Paper') that included the following endorsement of the so-called arm's length standard (ALS) for examining the reasonableness of transactions between related parties for tax purposes:

The arm's length standard is embodied in all U.S. tax treaties; it is in each major model treaty, including the U.S. Model Convention; it is incorporated into most tax treaties to which the United States is not a party; it has been explicitly adopted by international organizations that have addressed themselves to transfer pricing issues; and virtually every major industrial nation takes the arm's length standard as its frame of reference in transfer pricing cases. The United States should continue to adhere to the arm's length standard. ${ }^{1}$

What is the ALS, and why did the Treasury seek to defend it in these terms? The problem for which the ALS attempts to provide the solution may be illustrated by a simple example. Suppose that a product (e.g., computers) is manufactured by a corporation in country $A$, and then sold to a wholly-owned subsidiary of the manufacturer in country $B$, which proceeds to resell it to unrelated customers. In this common situation, the taxable profit of the subsidiary is determined by three factors: (i) the price at which it resells the computers to the unrelated customers, (ii) its expenses other than cost of goods sold, and (iii) the price which it pays its parent corporation for the computers. The first two of these factors are governed by market forces outside the control of the parent or the subsidiary. However, because the parent controls the

1 I.R.S. Notice 88-123, 1988-2 C.B. 458, 475 ('White Paper') (footnotes omitted). For examples of more recent statements along the same lines, see J. Iekel, 'Samuels Defends Revenue Estimating, Arm's Length Standard', 65 Tax Notes 1587 (16 December 1994); J. Turro, 'Treasury Continues to Champion Worldwide Arm's Length Standard' 66 Tax Notes 316 (16 January 1995). 
subsidiary, the third factor (the price for which the manufacturer sells the computers to the reseller, or the 'transfer price') is wholly within the control of the related parties. Accordingly, the potential for abuse arises because the related parties will seek to increase after-tax profits by manipulating the transfer price. If the effective tax rate in the manufacturer's country is higher, the price will be set as low as possible so as to channel all taxable profit to the reseller. Conversely, if the effective tax rate in the reseller's jurisdiction is higher, the transfer price will be as high as possible, so as to eliminate any taxable profit of the reseller and concentrate the entire profit in the hands of the manufacturer. But for tax considerations, the affiliated parties do not care what the transfer price is, since it merely reallocates profits within the affiliated group.

Given these facts, it is understandable that transfer pricing manipulation is one of the most common techniques of tax avoidance. This is especially true in the international sphere, as there are great differences in effective tax rates among jurisdictions. Indeed, some economists have argued that the ability to manipulate transfer prices is a major reason for the existence of multinational enterprises (MNEs), which are groups of affiliated corporations operating in more than one country. ${ }^{2}$ It is estimated that trading among such affiliates encompasses about one-third of world manufacturing trade, ${ }^{3}$ and that percentage is constantly increasing. The transfer pricing problem is, therefore, one of the major international tax policy challenges for the coming century.

The ALS, as traditionally conceived, responds to the transfer pricing problem by seeking to determine whether transactions between related taxpayers reflect their 'true' tax liability by comparing them to similar transactions between unrelated taxpayers dealing at arm's length. This was the definition of the ALS that was understood when the White Paper was published in $1988 .{ }^{4}$ However, as is reflected in the defensive tone of the Treasury's pronouncements, the White Paper was written at a time when this traditional conception of the ALS was coming under increasing criticism and suggestions for its replacement were rampant. In particular, the legislative history of the Tax Reform Act of 1986 indicates

${ }^{2} \mathrm{R}$. Gordon and J. Mackie-Mason, Why is there Corporate Taxation in a Small Open Economy? The Rule of Transfer Pricing and Income Shifting, National Bureau of Economic Research Working Paper No. 4690 (1994).

3 U.S. General Accounting Office, International Taxation: Problems Persist in Determining Tax Effects of Intercompany Prices (1992), pp. 62-3.

${ }^{4}$ White Paper, note 1 above, pp. 459-61. 
that Congress had mandated that the Treasury Department re-evaluate the continued viability of the ALS. ${ }^{5}$ The White Paper was issued in response to this mandate. However, despite the Treasury's findings, the process begun by the Congressional mandate eventually resulted in the abandonment of the ALS, as it was understood in 1988. Its replacement, in the United States and elsewhere, was a broader and more flexible method of determining the allocation of taxable profits between related entities. Although this broader method may also be characterised as 'arm's length', it is a different type of arm's length standard than the one defended by the White Paper. Indeed, the White Paper itself played a major part in the demise of the traditional ALS.

This chapter explores the process by which the traditional ALS became the dominant method for determining transfer prices for tax purposes, the reasons for its eventual downfall, and methods that can be used in its place. First, a few definitional points are in order. The traditional ALS refers primarily to a process by which the transfer price between affiliated taxpayers is determined by using comparables - either of the same product sold by one of the affiliated parties to an unrelated party, or the same product bought by an affiliated party from an unrelated party, or of the same product sold between two parties unrelated to the affiliated parties and to each other. This method of comparison is usually called the 'comparable uncontrolled price', or CUP method. ${ }^{6}$ In addition, the traditional ALS also encompasses two methods that likewise rely on comparables, but do not require a transaction in the same product. Under the 'cost plus' method, the transfer price is determined by comparing the manufacturer to a similar entity (under a more relaxed standard of comparability than under the CUP method), which is dealing with unrelated parties, and allocating to the manufacturer the costs borne by the unrelated comparable, plus the unrelated party's profit margin. ${ }^{7}$ The 'resale price' method is identical to the cost plus method except that it applies to the reseller rather than the manufacturer. ${ }^{8}$

The ALS, as traditionally conceived, is frequently contrasted with 'unitary', 'global' or 'formulary apportionment' methods, such as those used by some states. Here the entire profit of an affiliated group is allocated among its constituent entities by means of a formula (e.g., based

${ }^{5}$ H.R. Conf. Rep. No. 99-841, 99th Cong., 2d Sess. II-638 (1986).

6 See, e.g., Treas. Reg. s. 1.482-2(e)(2); Treas. Reg. s. 1.482-3(b).

7 See, e.g., Treas. Reg. s. $1.482-2(\mathrm{e})(4)$; Treas. Reg. s. 1.482-3(d).

8 See, e.g., Treas. Reg. s. 1.482-2(e)(3); Treas. Reg. s. 1.482-3(c). 
on each entity's assets, payroll and sales). ${ }^{9}$ The major difference between the ALS and the formulary method is that the ALS starts by treating each entity in an affiliated group as a separate taxpayer, hypothetically dealing with each other entity in the group at arm's length. Conversely, the formulary approach starts with the entire affiliated group as one unitary enterprise.

This chapter proposes that despite the common practice of contrasting the ALS and the formulary methods of dealing with the transfer pricing problem, they are actually not dichotomous. Instead, they form the two extreme ends of a continuum. ${ }^{10}$ The cost plus and resale price methods, which are included in the traditional ALS, already represent one step away from pure separate treatment of each entity in the group. This is because they involve taking the group's profits as a whole, subtracting the profit margin allocable to the manufacturer or the reseller on the basis of the comparables, and then allocating the residual profit to the other party.

Next on the continuum comes the 'comparable profit method' (CPM), which is a major innovation of the recent regulations under

${ }^{9}$ For examples of recent contributions to the debate about the ALS and formulary methods, see B. F. Miller, 'None are So Blind as Those Who Will Not See' 66 Tax Notes 1023 (13 February 1995); J. Turro, 'The Battle over Arm's Length and Formulary Apportionment' 65 Tax Notes 1595 (26 December 1994); W. I. Wilkins and K. W. Gideon, 'Memorandum to Worldwide Formulary Apportionment' 65 Tax Notes 1259 (5 December 1994); J. R. Hellerstein, 'Federal Income Taxation of Multinationals: Replacement of Separate Accounting with Formulary Apportionment' 60 Tax Notes 1131 (23 August 1993); L. M. Kauder, 'The Unspecific Federal Tax Policy of Arm's Length: A Comment on the Continuing Vitality of Formulary Apportionment at the Federal Level' 60 Tax Notes 1147 (23 August 1993); E. J. Coffill and P. Wilson, Jr, 'Federal Formulary Apportionment as an Alternative to Arm's Length Pricing: From the Frying Pan to the Fire?' 59 Tax Notes 1103 (24 May 1993); B. F. Miller, 'A Reply to “From the Frying Pan to the Fire"' 61 Tax Notes 241 (11 October 1993); R. Avi-Yonah, 'Slicing the Shadow: A Proposal for Updating U.S. International Taxation' 58 Tax Notes 1511 (15 March 1993); and L. M. Kauder, 'Intercompany Pricing and Section 482: A Proposal to Shift from Uncontrolled Comparables to Formulary Apportionment Now' 58 Tax Notes 485 (25 January 1993). For a recent proposal to implement formulary methods in the context of NAFTA, see P. R. McDaniel, 'Formulary Taxation in the North American Free Trade Zone: A Policy Perspective' (1993-4) 49 Tax L Rev. 691.

${ }^{10}$ This idea is stated briefly in B. J. Arnold and T. E. McDonnell, 'Report on the Invitational Conference on Transfer Pricing: The Allocation of Income and Expenses Among Countries' (1993) 61 Tax Notes 177, 1381, but is not fully developed there or elsewhere. See Amicus Brief of Council of State Governments, Barclays Bank PLC v. Franchise Tax Board, 114 S.Ct. 2268 (No. 92-1384) (1994) (a brief by the present writer, outlining this idea in the context of a recent case over the constitutionality of state formulary methods). 
section 482 of the Internal Revenue Code ('the Code'), under which the profit of either the manufacturer or the reseller is set by comparing it to the average profit earned by a very broad group of corporations operating in the same or a similar industry. ${ }^{11}$ The standard of comparison in this case is very relaxed, and one may indeed regard the CPM as a type of formula designed to ensure that the profits of the related party do not fall outside a reasonable range of profit margins earned by other corporations which are not truly comparable with the related party. ${ }^{12}$ As will be shown below, the CPM falls outside the traditional or narrow definition of the ALS, but it still uses some form of comparables.

Even further along on the continuum of possible methods of determining transfer prices is the 'profit split' method. This method was first introduced in the 1988 White Paper. ${ }^{13}$ Here, the allocation of profits is determined in two steps. First, the functions performed by each of the related parties are analysed and a market rate of return is allocated to each function on the basis of comparables. ${ }^{14}$ Then, the residual profit is split between the related parties on the basis of a formula, without using comparables. ${ }^{15}$ The profit split method is very close to the pure formulary apportionment end of the transfer pricing continuum, because it starts with the enterprise as a whole and allocates the profits in a formulary fashion. The only differences are that some of the profits are allocated on the basis of comparables, and that the formula used to split the rest is more flexible than the traditional assets, payroll and salesbased formula used by the states.

Consequently, the words 'arm's length' can be used in two ways to refer to two different possible ranges of solutions to the transfer pricing problem. Under the traditional or narrow definition, 'arm's length' refers to methods of determining transfer prices by using comparables, and encompasses only the CUP, cost plus and resale price methods. ${ }^{16}$ On the other hand, 'arm's length' can also be used to refer to any method of determining transfer prices that reaches results (i.e., a profit allocation) that are the same as those that would have been reached between unrelated parties. In this latter, broader sense, 'arm's length' can be used

11 Treas. Reg. s. 1.482-5. $\quad{ }^{12}$ Treas. Reg. s. $1.482-5$ (c).

13 White Paper, note 1 above, p. 490 . The profit split method has since been adopted as part of the current Treasury Regulations. See Treas. Reg. s. 1.482-6.

14 Treas. Reg. s. 1.482-6(b). ${ }^{15}$ Treas. Reg. s. 1.482-6(c).

16 'Arm's length' does not refer to CPM, because the standard of comparability for CPM is so loose that it is doubtful whether it can truly be regarded as relying on comparables, and it has therefore been excluded from the traditional definition of the ALS. 
to refer to the entire transfer pricing continuum, because even pure formulary apportionment may result in the same profit allocation as that which unrelated parties would have reached.

The next four parts of this chapter analyse the origins, rise, decline and fall of the traditional or narrow ALS, as applied to international transactions between related parties under section 482 of the Code and its predecessors. ${ }^{17}$ The analysis will show that despite the Treasury's affirmation of the traditional ALS in its 1988 White Paper, ${ }^{18}$ this narrow conception of the standard was already obsolete by 1988 in the large majority of cases, insofar as the United States' approach to international taxation was concerned. Subsequent developments, especially the 19921995 proposed, temporary and final regulations under section 482 of the Code, merely strengthened the nails in its coffin. The last sections of the chapter will focus on post-1995 litigation and then on the following questions: (1) Why has the traditional ALS proven so inadequate? (2) What methods are now used to supplement it? and (3) What additional improvements can be made in resolving the transfer pricing problem?

\subsection{Origins (1917-1928)}

Transfer pricing manipulation is one of the simplest ways to avoid taxation. It is, thus, not surprising that the predecessors of section 482 of the Code, legislation designed to combat such manipulation, date back almost as far as the modern income tax itself. They originated in regulation 41, chapters 77 and 78, of the War Revenue Act of 1917, which gave the Commissioner authority to require related corporations to file consolidated returns 'whenever necessary to more equitably determine the invested capital or taxable income.' ${ }^{19}$ The earliest direct predecessor of section 482 of the Code dates to 1921, when the Commissioner

17 The literature on s. 482 is immense. Some major contributions include J. P. Fuller, 'Section 482 Revisited' (1976) 31 Tax L Rev. 475; James P. Fuller, 'Section 482: Revisited Again' (1990) 45 Tax L Rev. 421; Richard O. Loengard, 'The Section 482 Pot Boils On: Comments on Recent Developments' (1991) 469 Tax Forum; Dale W. Wickham, 'The New U.S. Transfer Pricing Tax Penalty: A Solution, or a Symptom of the Cause, of the International Transfer Pricing Puzzle?' (1991) 18 Int'l Tax J1. The best historical survey of the ALS up to 1986 is contained in Stanley I. Langbein, 'The Unitary Method and the Myth of Arm's Length' 30 Tax Notes 625 (17 February 1986) (focusing on the development of the ALS in the international context).

18 See note 1 above and accompanying texts.

19 T.D. 2694, 20 Treas. Dec. Int. Rev. 294, 321 (1918). See also War Revenue Act of 1917, Ch. 63,40 Stat. 300 (1917). 
was authorised to consolidate the accounts of affiliated corporations 'for the purpose of making an accurate distribution or apportionment of gains, profits, income, deductions, or capital between or among such related trades or business. ${ }^{20}$ This legislation was enacted, in part, because of the tax avoidance opportunities afforded by possessions corporations, which were ineligible to file consolidated returns with their domestic affiliates. ${ }^{21}$ Thus, the problem of international tax avoidance through related corporations was one of the original motives for the enactment of the earliest predecessor of section 482 of the Code. ${ }^{22}$ In 1928, the provision was removed from the consolidated return provisions (which were eliminated).

\subsubsection{Section 45: allocation of income and deductions}

In any case of two or more trades or businesses (whether or not incorporated, whether or not organised in the United States, and whether or not affiliated) owned or controlled directly or indirectly by the same interests, the Commissioner is authorised to distribute, apportion or allocate gross income or deductions between or among such trades or businesses, if he determines that such distribution, apportionment or allocation is necessary in order to prevent evasion of taxes or clearly to reflect the income of any of such trades or businesses. ${ }^{23}$

This language is almost identical to section 482 of the Code as it read prior to the Tax Reform Act of $1986 .^{24}$ The legislative history of section 45 of the Code, in its entirety, is as follows.

Section 45 is based upon section 240(f) of the 1926 Act, broadened considerably in order to afford adequate protection to the government

${ }^{20}$ Revenue Act of 1921, Ch. 136, s. 240(d), 42 Stat. 260 (1921) (re-enacted in Revenue Act of 1924, Ch. 234, s. 240(d), 43 Stat. 288 (1924), and Revenue Act of 1926, Ch. 27, s. 240 (f), 44 Stat. 46 (1926)). Unlike the current IRC s. 482 , these earlier provisions allowed taxpayers to request that the Commissioner permit consolidation.

21 'Subsidiary corporations, particularly foreign subsidiaries, are sometimes employed to "milk" the parent corporation, or otherwise improperly manipulate the financial accounts of the parent company.' H.R. Rep. No. 350, 67th Cong., 1st Sess. 14 (1921); see also S. Rep. No. 275, 67th Cong., 1st Sess. 20 (1921).

22 For surveys of the history of IRC s. 482, see White Paper, note 1 above, ch. 2; Eli Lilly \& Co. v. Commissioner, 84 T.C. 996, 1114-15 (1985).

${ }^{23}$ Revenue Act of 1928 , Ch. 852 , s. 45,45 Stat. 806 (1928).

24 Among the few changes, 'Organizations' was added to 'trades or businesses', 'credits or allowances' were added to 'gross income or deductions', and 'the Secretary or his delegate may' was substituted for 'the Commissioner is authorized to'. See IRC s. 482. 
made necessary by the elimination of the consolidated return provisions of the 1926 Act. The section of the new bill provides that the Commissioner may, in the case of two or more trades or businesses owned or controlled by the same interests, apportion, allocate or distribute the income or deductions between or among them, as may be necessary in order to prevent evasion (by the shifting of profits, the making of fictitious sales and other methods frequently adopted for the purpose of 'milking'), and in order clearly to reflect their true tax liability. ${ }^{25}$

Senator Gifford stated on the floor that 'what worries us is that any two of these corporations can get together and take advantage of questionable sales to each other to get deductions. ${ }^{26}$ Senator Green replied that 'Section 45 permits the bureau to allocate the income where it belongs. It ... does not permit these corporations to place the expenses just where they want to put them. ${ }^{27}$

Congress' focus in enacting the predecessor of section 482 of the Code was, thus, to prevent tax evasion and to clearly reflect 'true' tax liability. However, there was no discussion of what the standard of 'true' liability was. In 1935, the Service issued regulations under section 45 of the Code, which stated that the following standards would govern its application.

\subsubsection{Scope and purpose}

The purpose of section 45 is to place a controlled taxpayer on a tax parity with an uncontrolled taxpayer, by determining, according to the standard of an uncontrolled taxpayer, the true net income from the property and business of a controlled taxpayer. The interests controlling a group of controlled taxpayers are assumed to have complete power to cause each controlled taxpayer so to conduct its affairs that its transactions and accounting records truly reflect the net income from the property and business of each of the controlled taxpayers. If, however, this has not been done, and the taxable net incomes are thereby understated, the statute contemplates that the Commissioner shall intervene, and, by making such distributions, apportionments or allocations as he may deem necessary of gross income or deductions, or of any item or element

${ }^{25}$ H.R. Rep. No. 2, 70th Cong., 1st Sess. 16-17 (1927); see also S. Rep. No. 960, 70th Cong., 1st Sess. 24 (1928).

${ }^{26} 69$ Cong. Rec. 605, cited in J. Seidman, Legislative History of Federal Income Tax Laws 1938-1861 (1938), p. 522.

27 Ibid. 
affecting net income, between or among the controlled taxpayers constituting the group, shall determine the true net income of each controlled taxpayer. The standard to be applied in every case is that of an uncontrolled taxpayer dealing at arm's length with another uncontrolled taxpayer. $^{28}$

Thus, the ALS, under US tax law, was born. This section of the regulations, in very similar language, remained in effect under section 482 of the Code until the recently-issued modifications. ${ }^{29}$

However, the regulations were not modified to explain what methods should be used to arrive at an arm's length price until 1968. Previously, this task was left to the courts.

\subsection{Rise (1928-1972)}

The early cases applying section 45 of the Code did not mention the ALS. Instead, they focused on the statutory terms 'evasion of taxes' and 'clear reflection of income. ${ }^{30}$ It was not until the 1935 regulations were issued, that the arm's length nature of the transaction between related parties came into focus. ${ }^{31}$ However, for a long period thereafter, the courts applied a wide variety of standards to determine what constituted a transaction that clearly reflected the taxpayer's income. ${ }^{32}$

Seminole Flavor Co. v. Commissioner ${ }^{33}$ is a good example of these early cases. The issue was whether transactions between a corporation and a partnership organised to market the corporation's products should be adjusted to shift income from the partnership to the corporation. ${ }^{34}$

28 Essex Broadcasters, Inc. v. Commissioner, 2 T.C. 523, 528 (1943).

29 Treas. Reg. s. $1.482-1(\mathrm{~b})(1)$ redesignated as Treas. Reg. s. $1.482-1 \mathrm{~A}(\mathrm{~b})(1)$; cf. Temp. Treas. Reg. s. 1.482-1T(a)(1) and (b) (1993); Treas. Reg. s. 1.482-1(b)(1). See generally discussion in section 3.5 below. The ALS was adopted under the influence of concurrent developments in international taxation and the initial evolution of model standards. See S. I. Langbein, 'The Unitary Method and the Myth of Arm's Length' (1986) 30 Tax Notes 625, 628-34.

30 See, e.g., Asiatic Petroleum Co. v. Commissioner, 31 B.T.A. 1152, 1159 (1935) (stating that a sale was not 'arm's length' but not focusing on this issue); aff'd 79 F.2d 234 (1935).

31 See, e.g., G.U.R. Co.v. Commissioner, 41 B.T.A. 223 (1940) (sale of stock at seven times its market value not arm's length); aff'd 117 F.2d 187 (1940).

32 See, e.g., National Securities Corp. v. Commissioner, 137 F.2d 600 (3rd Cir. 1943); cert. denied 320 U.S. 794 (1943). This leading case for the application of section 45 to tax-free transfers to corporations surveys the history of s. 45 but does not mention the ALS.

334 T.C. 1215 (1945). ${ }^{34}$ Ibid. 1229. 
The Tax Court, in holding for the taxpayer, stated that the arm's length nature of the transaction should be determined by whether it was 'fair and reasonable', and that the question of whether unrelated parties would have entered into the same agreement was irrelevant. ${ }^{35}$ It then went on to hold that:

The commission fixed does not appear to be out of line with petitioner's own experience [i.e., its expenses for marketing prior to forming the partnership]. On this basis the transaction would seem to be fair and entitled to classification as an arm's length transaction. Whether any such business agreement would have been entered into by petitioner with total strangers is wholly problematical. ${ }^{36}$

Other cases from the same period show similar tendencies to apply a variety of standards and to ignore the question of whether comparables exist. The standards employed included whether the transaction was 'fair' on the basis of the functions performed by the parties; ${ }^{37}$ whether the related party paid 'full fair value'; ${ }^{38}$ and whether the prices paid would have been considered 'fair and reasonable' in the trade. ${ }^{39}$

On the other hand, in Hall v. Commissioner, ${ }^{40}$ a somewhat later Tax Court case, a comparable was used to establish the arm's length price. Hall involved sales to a Venezuelan marketing affiliate at cost plus 10 per cent (a price which amounted to a discount of over 90 per cent from the regular list price) when unrelated distributors of the same product received a discount of only 20 per cent. ${ }^{41}$ The Tax Court held that gross income had been arbitrarily shifted to the Venezuelan corporation, and that the Commissioner's allocation 'reflected Hall's income as if he had been dealing with unrelated parties. That, of course, was the purpose of the statute. ${ }^{42}$

The early cases, thus, appear inconsistent in their application of arm's length. The question of whether the ALS should always be applied was

35 Ibid. 1232.

${ }^{36}$ Ibid. 1233; see also Palm Beach Aero Corp. v. Commissioner, 17 T.C. 1169, 1176 (1952) ('fair consideration which reflects arm's length dealing').

37 Grenada Industries, Inc. v. Commissioner, 17 T.C. 231, 260 (1951), aff'd 202 F.2d 873 (5th Cir. 1953); aff'd 346 U.S 819 (1953).

38 Friedlander Corp. v. Commissioner, 25 T.C. 70, 77 (1955); Motors Securities Co., Inc. v. Commissioner, 11 T.C.M. 1074, 1082 (1952).

39 Polak's Frutal Works, Inc. v. Commissioner, 21 T.C. 953, 976 (1954).

4032 T.C. 390 (1959), aff'd 294 F.2d 82 (5th Cir. 1961). ${ }_{41}^{4}$ Ibid. 410.

42 Ibid. (citing Asiatic Petroleum Co. v. Commissioner, 31 B.T.A. 1152 (1935), which did not, however, involve a direct application of the ALS). 
finally raised in Frank v. International Canadian Corporation, ${ }^{43}$ decided in 1962, which was twenty-seven years after the initial promulgation of the standard in regulations. ${ }^{44}$ The case involved transfer prices for sales of chemicals by a US parent to a Western hemisphere trade corporation (WHTC). The parties stipulated that the sales reflected a 'reasonable price and profit' between the two corporations, and the District Court found that the Commissioner had thereby stipulated himself out of court on the section 45 issue. ${ }^{45}$ The Commissioner appealed, arguing that the District Court used the 'reasonable return' standard instead of the proper arm's length standard. The Court of Appeals for the Ninth Circuit affirmed in the following terms:

\begin{abstract}
We do not agree with the Commissioner's contention that 'arm's length bargaining' is the sole criterion for applying the statutory language of section 45 in determining what the 'true net income' is of each 'controlled taxpayer'. Many decisions have been reached under section 45 without reference to the phrase 'arm's length bargaining' and without reference to Treasury Department Regulations and Rulings which state that the talismanic combination of words - 'arm's length' - is the 'standard to be applied in every case'. For example, it was not any less proper for the District Court to use here the 'reasonable return' standard than it was for other courts to use 'full fair value', 'fair price, including a reasonable profit', 'method which seems not unreasonable', 'fair consideration which reflects arm's length dealing', 'fair and reasonable', 'fair and reasonable' or 'fair and fairly arrived at', or 'judged as to fairness', all used in interpreting section $45 .^{46}$
\end{abstract}

Thus, the Ninth Circuit essentially invalidated the regulations, and held that it was not necessary to establish what unrelated taxpayers would have done in order to clearly reflect the 'true' income and correct tax liability of related parties. ${ }^{47}$

One can only speculate as to what would have happened had the courts been left free to develop their own definition of 'fair' or

43308 F.2d 520 (9th Cir. 1962). $\quad{ }^{44}$ See note 28 above and accompanying texts.

45 Frank, note 43 above, 308 F.2d at 528.

46 Ibid. 528-9 (citations omitted) (citing Friedlander Corp. v. Commissioner, 25 T.C. 70, 77 (1955); Grenada Industries, Inc. v. Commissioner, 17 T.C. 231, 260 (1951); Motors Securities Co., Inc. v. Commissioner, 11 T.C.M. 1074, 1082 (1952); Palm Beach Aero Corp. v. Commissioner, 17 T.C. 1169, 1176 (1952); Polak's Frutal Works, Inc. v. Commissioner, 21 T.C. 953, 975-6 (1954); and Seminole Flavor Co. v. Commissioner, 4 T.C. 1215, 1232 (1945).

47 Cf. Treas. Reg. 86, s. 45-1(b) (1935). 
'reasonable' without having to adhere to the ALS. ${ }^{48}$ During the same era as the Frank decision, major developments were taking place in Washington that would ultimately lead to the establishment of standards under section 482 of the Code (as section 45 of the Code had now been renumbered). The early 1960s were marked by a rise in concern on the part of the Treasury that domestic corporations were achieving deferral through transfer pricing practices with tax haven affiliates, and that foreign corporations were avoiding taxes altogether by artificially lowering the profits of their US affiliates. The Treasury contended that section 482 of the Code was not effectively protecting the US tax jurisdiction. ${ }^{49}$

Congress responded with legislation intended to stop these perceived abuses. Section 6 of H.R. 10650, as introduced by the House Committee on Ways and Means, provided for a new Code section, section 482(b)..$^{50}$ Under the House proposal, in section 482 cases involving international transfers of tangibles, unless the taxpayer could demonstrate an arm's length price (defined, in accordance with the traditional view, as a price based on a matching or comparable adjustable transaction), or unless the taxpayer and the IRS could agree on a different method, the transfer

${ }^{48}$ See, e.g., Nestle Company, Inc. v. Commissioner, 22 T.C.M. 46, 62 (1963), decided just after Frank and before Oil Base, Inc. v. Commissioner, 23 T.C.M. 1838 (1964), discussed at note 56 below, in which the Tax Court analysed the royalty rate for a valuable intangible (for which no comparables could in any case be found) in an eminently sensible way under a 'reasonableness' standard, including a renegotiation of the rate to reflect profitability, without having to resort to an 'arm's length' analysis. See also Ballentine Motor Co., Inc. v. Commissioner, 39 T.C. 348, 357 (1962), aff'd 321 F.2d 796 (4th Cir. 1963) ('taxpayers owned or controlled by the same interests may enter into transactions inter se and if fair, or resulting from arm's length bargaining, such transactions will be undisturbed'). This decision was also rendered shortly after Frank.

49 Hearings on the President's 1961 Tax Recommendations Before the Committee on Ways and Means, 87th Cong., 1st Sess., vol. 4 at 3549 (1961) (statement of Commissioner Caplin); see Langbein, 'The Unitary Method and the Myth of Arm's Length', note 17 above, 643-4. These concerns are remarkably similar to those voiced currently. See, e.g., R. L. Kaplan, 'Treasury Blasted over Alleged Transfer Pricing Shenanigans', 55 Tax Notes 150 (13 April 1992); R. L. Kaplan, 'International Tax Enforcement and the Special Challenge of Transfer Pricing' (1990) U Ill. L Rev. 299.

${ }^{50}$ H.R. 10650, 87th Cong., 2d Sess. s. 6 (1962). Important among the other provisions that were introduced to curb transfer pricing abuses was subpart $\mathrm{F}$, adopted in 1962. IRC s. 952-64. This provision defines the income of controlled foreign corporations that is not eligible for tax deferral and for which dividends to the US parent must be imputed. For a brief overview of the relationship between IRC s. 482 and subpart F, see Kaplan, 'International Tax Enforcement' note 49 above, 307-11. 
price would be determined under a formula based on assets, compensation and expenses related to the transferred tangible property. ${ }^{51}$

The House Report explained the intent of section 6 of the bill as follows:

Present law in section 482 authorizes the Secretary of the Treasury to allocate income between related organizations where he determines this allocation is necessary in order to prevent evasion of taxes or clearly to reflect the income of any such organizations'. This provision appears to give the Secretary the necessary authority to allocate income between a domestic parent and its foreign subsidiary. However, in practice the difficulties in determining a fair price under the provision severely linit the usefulness of this power especially where there are thousands of different transactions engaged in between a domestic company and its foreign subsidiary.

Because of the difficulty in using the present section 482, your committee has added a subsection to this provision authorizing the Secretary of the Treasury or his delegate to allocate income in the case of sales or purchases between a U.S. corporation and its controlled foreign subsidiary on the basis of the proportion of the assets, compensation of the officers and employees, and advertising, selling and promotion expenses attributable to the United States and attributable to the foreign country or countries involved. This will enable the Secretary to make an allocation of the taxable income of the group involved (to the extent it is attributable to the sales in question) whereas in the past under the existing section 482 he has attempted only to determine the fair market sales price of the goods in question and build up from this to the taxable income - a process much more difficult and requiring more detailed computations than the allocation rule permitted by this bill.

The bill provides, however, that the allocation referred to will not be used where a fair market price for the product can be determined. It also provides that other factors besides those named can be taken into account. In addition, it provides that entirely different allocation rules may be used where this can be worked out to mutual agreement of the Treasury Department and the taxpayer. ${ }^{52}$

Predictably, the taxpayer community responded by lobbying Congress to remove section 6 from H.R. 10650, claiming that the regulatory authority under section 482 of the Code was sufficient to curb abuses. ${ }^{53}$ Their efforts were rewarded in the Senate version of the bill, which

51 H.R. 10650, 87th Cong., 2d Sess. s. 6 (1962).

52 H.R. Rep. No. 1447, 87th Cong., 2d Sess. 28 (1962).

53 See, e.g., Hearings on H.R. 10650 before the Senate Committee on Finance, 87 th Cong., $2 \mathrm{~d}$ Sess. 560-1, 725-6 (1962) ('Hearings') (statements by W. Slowinski and R. Landolt). 
omitted the section. In conference, the House receded. The Conference Report states the reasons as follows:

The conferees on the part of both the House and the Senate believe that the objectives of section 6 of the bill as passed by the House can be accomplished by amendment of the regulations under present section 482. Section 482 already contains broad authority to the Secretary of the Treasury or his delegate to allocate income and deductions. It is believed that the Treasury should explore the possibility of developing and promulgating regulations under this authority which would provide additional guidelines and formulas for the allocation of income and deductions in cases involving foreign income. ${ }^{54}$

The Treasury took three years to respond to this invitation. ${ }^{55}$ In the meantime, however, significant new developments were taking place in the courts. Oil Base, Inc. v. Commissioner ${ }^{56}$ represented a classic case of the application of the ALS to sales commissions paid by a US corporation to its Venezuelan marketing affiliate. These commissions were about twice the amount that the same corporation had paid its previous unaffiliated distributor of the same product in Venezuela, and were twice the amount it was currently paying to distributors in other countries. The taxpayer, however, argued that the Frank standard should be applied instead of arm's length, and that since it still retained higher profits from export sales to Venezuela even after the double commission than from domestic sales, the commissions were 'reasonable' under Frank. The Tax Court, in a memorandum decision, disagreed. It held that:

It is unnecessary for us to decide whether the sole standard in cases under section 482 is one of an amount which would be arrived at in arm's length transactions between unrelated parties. The commissioner has been given much latitude in his use of section 482 when necessary to prevent the evasion of Federal income tax by shifting of profits between taxpayers subject to common control. The burden is on petitioner to show error in respondent's allocation. There is no evidence to show that the percentage return retained by petitioner on domestic sales would represent a

${ }^{54}$ H.R. Rep. No. 2508, 87th Cong, 2d Sess. 18-19, reprinted in 1962 U.S.C.C.A.N. 3732, 3739.

55 Regulations, which did not accept the invitation to use a formula approach, were proposed in 1965, Prop. Treas. Reg. ss. 1.482-1(d) and 2, 30 Fed. Reg. 4256 (31 March 1965) (these regulations did not include any provisions on sales of tangibles), withdrawn and reproposed in 1966, Prop. Treas. Reg. ss. 1.482-1(d) and 2, 31 Fed. Reg. 10394 (31 March 1966), and issued in final form in 1968, Treas. Reg. s. 1.482. See discussion at note 71 below.

Oil Base, Inc. v. Commissioner, 23 T.C.M. 1838 (1964). 
reasonable return on export sales. There is likewise no evidence to show that the amount of commissions and discounts paid to Oil Base, Venezuela, represented a reasonable amount, a fair amount, or an amount which would meet any of the other criteria referred to by the Court in Frank. Certainly the fact that these commissions are almost double those paid by petitioner to unrelated persons in arm's length transactions is evidence that they were not fair and reasonable. ${ }^{57}$

Presumably, the taxpayer in Oil Base was encouraged to litigate, despite the egregious facts, because appeal lay to the Ninth Circuit. On appeal, the taxpayer, citing Frank, repeated the argument that the Commissioner erred in applying a standard of arm's length bargaining that was not in the statute. The Court of Appeals, however, held that the application of arm's length was appropriate:

We cannot agree. Where, as here, the extent of the income in question is largely determined by the terms of business transactions entered into between two controlled corporations it is not unreasonable to construe 'true' taxable income as that which would have resulted if the transactions had taken place upon such terms as would have applied had the dealings been at arm's length between unrelated parties.

Frank v. International Canadian Corporation [308 F.2d. 520 (9th Cir. 1962)], did not hold that the arm's length standard established by regulation was improper. It held that it was not 'the sole criterion' for determining the true net income of each controlled taxpayer. However, permissible departure from the regulation's arm's length standard was, under the facts of that case, very narrowly limited and the holding has no application to the facts before us.

We conclude that the arm's length bargaining standard was properly applied pursuant to regulation. Hall v. Comm'r, 294 F.2d 82 (5th Cir. $1961)^{58}$

In a footnote, the Ninth Circuit specified that Frank only applied in cases where (a) there was no evidence of an arm's length price, and (b) because of the 'complexity of the circumstances ... it would have been difficult for the court to hypothesize an arm's length transaction. ${ }^{59}$

It is difficult to reconcile this reading of Frank with the list of possible standards given by the Frank panel four years earlier, which relegated the ALS to a very minor role. In effect, the Ninth Circuit overruled Frank, holding that the ALS must be applied not only when comparables exist,

57 Ibid. 1845-6 (citations omitted).

58 Oil Base, Inc. v. Commissioner, 362 F.2d 212, 214 (9th Cir. 1966) (footnote omitted).

59 Ibid. 214; see also note 5 above. 
but also when they do not exist, as the court can 'hypothesise' a comparable. This abrupt reversal was very likely influenced by the egregious facts of Oil Base and by the difficulties in applying a 'reasonableness' standard. It also seems likely that the Tax Court and the Ninth Circuit were influenced by the perception of widespread abuse as a result of the Washington hearings on the Revenue Act of 1962, and by the endorsement of the Commissioner's powers in the legislative history of that Act. ${ }^{60}$

The Commissioner's victory in Oil Base was followed by a series of cases which applied the ALS, although not always to the Commissioner's satisfaction. In Johnson Bronze Co. v. Commissioner, ${ }^{61}$ the taxpayer formed an international marketing subsidiary in Panama for the majority of its foreign sales accounts. The Commissioner reallocated 100 per cent of the subsidiary's income to the parent under section 482 of the Code. The Tax Court held that the 100 per cent allocation was arbitrary and unreasonable. ${ }^{62}$ In determining the proper allocation, the court held that 'the standard to be applied in every case is that of an uncontrolled taxpayer dealing at arm's length with another uncontrolled taxpayer.' ${ }^{63}$ In a footnote, the court referred to Frank as requiring a choice between the 'reasonable' and 'arm's length' standards, but stated that 'on this subject we shall only say that, on the facts of this case, the only reasonable price charged by petitioner would be one which would have been arrived at if the parties were at arm's length.6 ${ }^{64}$ The court then held that the allocation should be based on the prices charged by unrelated parties that bought the same products from the taxpayer for resale in foreign markets. ${ }^{65}$

Eli Lilly \& Co. v. Commissioner, ${ }^{66}$ the first of several section 482 cases involving pharmaceutical manufacturers, involved transfer pricing between Eli Lilly \& Co. (Lilly) and its subsidiary which qualified as a WHTC. The Commissioner based his reallocation on the profit earned by Lilly on sales to domestic distributors, arbitrarily divided in half to reflect volume discount. The Claims Court agreed, holding that Lilly's contention that it should be allowed to benefit from the tax subsidy to

60 See Hearings, note 53 above, 3549; Langbein, 'The Unitary Method and The Myth of Arm's Length', note 17 above, 643-4.

6124 T.C.M. (CCH) 1542 (1965), ${ }^{62}$ Ibid. 1556.

63 Ibid. (citing Treas. Reg. s. $1.482-(\mathrm{b})(1)$ ).

64 Ibid. 1556 and see note 3 above (1965) (Oil Base is not cited).

${ }^{65}$ Ibid. $1557 . \quad{ }^{66} 372$ F.2d 990 (1967). 
WHTCs 'would require the court to ignore the provisions of Treas. Reg. $1.482-1$ ', requiring the application of the ALS. This is because if the subsidiary were unrelated it would not have been able to retain all the profit on the sales. ${ }^{67}$

Lilly then cited Frank, in arguing that its allocation was motivated by business purposes and was 'fair' and 'reasonable', and thus that the ALS should not control. The Court of Claims disagreed:

The Ninth Circuit has since indicated that only a very narrow departure from the arm's length standard was allowed in the particular circumstances of Frank [citing Oil Base]. Moreover, even accepting Eli Lilly's interpretation that Frank establishes a criterion of a fair and reasonable price, such a price can best be determined by hypothesizing to an arm's length transaction. The thrust of section 482 is to put controlled taxpayers on a parity with uncontrolled taxpayers. Consequently, any measure such as 'fair and reasonable' or 'fair and fairly arrived at' must be defined within the framework of 'reasonable' or 'fair' as among unrelated taxpayer's. Simply because a price might be considered 'reasonable' or 'fair' as a business incentive in transactions among controlled corporations, does not mean that unrelated taxpayers would so consider it. Thus, even if the arm's length standard is not the sole criterion, it is certainly the most significant yardstick. ${ }^{68}$

The problem, as the taxpayer pointed out, is that in the absence of any comparables, it is unclear how the arm's length price should be 'hypothesised'. To this question, the Court of Claims gave no answer. It rejected the comparables offered by Lilly (bulk sales to government agencies) because the market was not comparable, yet accepted the revenue agent's arbitrary decision to cut the profits of the Western hemisphere trade affiliates by half because the results were 'reasonable. ${ }^{69}$ When examining the outcome, it is hard to see what relevance the ALS had to the court's ultimate determination. ${ }^{70}$

In 1968, the regulations under section 482 of the Code were finalised, and thereafter, they formed the starting point of the analysis in the courts. ${ }^{71}$ With few changes, these regulations applied to transfer pricing until the temporary regulations became effective in April 1993. ${ }^{72}$ Despite

67 Ibid. 997. ${ }^{68}$ Ibid. $1000 . \quad{ }^{69}$ Ibid. 997.

70 See also Young \& Rubicam, Inc. v. United States, 410 F.2d 1233 (1969) (applying the ALS to services on the basis of Eli Lilly and Oil Base, but doing so without comparables).

71 T.D. 6952, 1968-1 C.B. 218 (1968). See S. S. Surrey, 'Treasury's Need to Curb Tax Avoidance in Foreign Business Through Use of 482' (1968) 28 J. Taxation 75 (discussing the policy behind these regulations).

72 See T.D. 8470 , 1993-1 C.B. 90 (1993). 
the invitation in the legislative history of the 1962 Act, the Treasury made no attempt to devise 'formulas' to apply section 482 of the Code. ${ }^{73}$ Instead, for the first time, the regulations attempted to establish rules for applying the ALS to specific types of transactions, but with different degrees of specificity. ${ }^{74}$ For services, the regulations merely recited the ALS without any guidance as to its application in the absence of comparables. ${ }^{75}$ For intangibles, the regulations contemplated a failure to find comparables. They list twelve factors to be taken into account, but without establishing any priority or relative weight among them. ${ }^{76}$

The greatest detail was given for transfers of tangible property. Treasury Regulation section 1.482-2(e) described the three methods that should be used in determining an arm's length price: the comparable uncontrolled price (CUP) method, the resale price method, and the cost plus method, in that order of priority. ${ }^{77}$ All three methods relied on finding comparable transactions, either directly or by reference to appropriate mark-ups. ${ }^{78}$ In the absence of comparables, the regulations stated that:

Where none of the three methods of pricing ... can reasonably be applied under the facts and circumstances as they exist in a particular case, some appropriate method of pricing other than those described in subdivision (ii) of this subparagraph, or variations on such methods, can be used. ${ }^{79}$

The courts were, therefore, left free to determine their own "fourth methods' in the absence of comparables.

These regulations effectively ensured that the courts would apply the ALS. A 1970 case, Woodward Governor Co. v. Commissioner, ${ }^{80}$ may have represented the last challenge to the standard. The taxpayer organised foreign subsidiaries to act as marketing agents for overseas sales of

${ }^{73}$ This may have been the result of Assistant Secretary Surrey's adherence to the ALS. The Treasury may also have felt that it lacked the authority to promulgate a formulary system. See Langbein, 'The Unitary Method and the Myth of Arm's Length', note 17 above, 648 .

${ }^{74}$ On the 'radical' nature of the regulations and their departure from earlier models see Langbein, ibid. 645-6. These regulations underlay the successful US attempt to establish the ALS as the international 'norm', as reflected in the White Paper, note 1 above and accompanying texts. See Langbein, ibid. 646-54.

75 Treas. Reg. s. $1.482-2($ b) (3).

${ }^{76}$ Treas. Reg. s. $1.482-2(d)(2)$.

Treas. Reg. s. $1.482(\mathrm{e})(1)(\mathrm{ii}) . \quad{ }^{78}$ Treas. Reg. s. $1.482-2(\mathrm{e})(2)-(4)$.

79 Treas. Reg. s. 1.482-2(e)(1)(iii). This language did not appear in the 1966 version of the regulations, which did not say what should be done in the absence of comparables. See Prop. Treas. Reg. s. 1.482-2, 31 Fed. Reg. 10394 (1966).

8055 T.C. $56(1970)$. 
aircraft parts. The Commissioner applied the resale price method in reallocating income to the taxpayer. The taxpayer argued that the regulations were invalid in their requirement that the ALS should govern all cases. In the alternative, they argued that if the ALS should be applied, the CUP method should be used on the basis of sales of the same parts to General Electric. The Tax Court accepted the latter argument and therefore did not reach the former. ${ }^{81}$

In the meantime, other courts were finding that the ALS must be applied in section 482 cases. Baldwin-Lima-Hamilton Corp. v. United States $^{82}$ involved transfer pricing between the taxpayer and its WHTC subsidiary. The Commissioner reallocated all of the income of the subsidiary to the taxpayer. The district court held that the reallocation was arbitrary, and upheld the taxpayer's allocation based on pricing studies using assumptions that were 'tipped in the taxpayer's favor', by using inappropriate comparables. ${ }^{83}$ The Court of Appeals reversed in part, and remanded to the district court for partial reallocation on the basis of the ALS, stating that the district court 'should reject those aspects of the [taxpayer's] theories which do not meet the arm's length standard. ${ }^{84}$

United States Gypsum Co. v. United States, ${ }^{85}$ involved two section 482 issues: shipping fees paid by the taxpayer to its Panamanian subsidiary and transfer pricing for goods sold by the taxpayer to its WHTC. The district court held for the taxpayer on both issues. On the shipping issue, it held that the amounts were 'reasonable and ... equal to an arm's length charge' because they were 'within the range' of unrelated party prices (based on comparables). ${ }^{86}$ On the transfer pricing issue, the district court held that even though the prices were arbitrarily set to shift income to the WHTC, on the basis of cases like Frank and Polak's Frutal which allowed similar mark-ups, the prices were 'not unreasonable' (which the district court considered to be automatically equivalent to arm's length). ${ }^{87}$

The Court of Appeals for the Seventh Circuit affirmed the first holding and reversed the second. ${ }^{88}$ On the shipping issue, the Seventh Circuit had considerable misgivings as to whether the alleged

81 Ibid. 65-8. $\quad{ }^{82} 435$ F.2d 182 (1970). $\quad{ }^{83}$ Ibid. 186-7. $\quad{ }^{84}$ Ibid.

85304 F.Supp. 627 (N.D. Ill. 1969), aff'd in part and rev'd in part, 452 F.2d 445 (7th Cir. 1971).

${ }^{86}$ Ibid. 634. ${ }^{87}$ Ibid. 644-5.

${ }^{88}$ U.S. Gypsum Co. v. United States, 452 F.2d 445, 449 (7th Cir. 1971). 
comparables were indeed comparable, and whether unrelated parties would not have adjusted the terms of the contract once the profits that the shipping subsidiary was making became clear, but affirmed under a 'clearly erroneous' standard. ${ }^{89}$ On the transfer pricing issue, the Seventh Circuit reversed, rejecting the district court's reliance on Frank and its predecessors and its application of a 'reasonableness' standard:

We do not consider the cited cases helpful in deciding whether, as a matter of fact, USG's prices to [the WHTC] were the same as would have been reached in arm's length dealing. Insofar as these cases support a proposition that there may be 'reasonable' prices, different from those which would have been reached in arm's length dealing, which will result in clearly reflecting the income of controlled taxpayers, we respectfully decline to follow them. ${ }^{90}$

Thus, the Seventh Circuit held, as argued by the Commissioner, that applying the ALS was mandatory in all section 482 cases. $^{91}$ Two other cases from approximately the same period illustrate the courts' determination to adhere to the ALS even when the Commissioner attempted to apply a different standard. PPG Industries, Inc. v. Commissioner ${ }^{92}$ involved the application of section 482 of the Code to a Swiss marketing subsidiary of a US manufacturer of glass, paint and chemical products. The Tax Court held for the taxpayer on the grounds that (a) the Commissioner's original allocation, based on the Source Book of Statistics of Income, was arbitrary and did not meet the ALS; ${ }^{93}$ (b) most of the taxpayer's sales were at arm's length prices based on comparables; ${ }^{94}$ and (c) the Commissioner's comparable for the remaining sales was inappropriate, and the taxpayer's allocation was 'fair' and 'reasonable' and therefore met the arm's length standard. ${ }^{95}$

Ross Glove Co. v. Commissioner ${ }^{96}$ represents the application of section 482 of the Code to an inbound transaction, involving the sale of sheepskins to the taxpayer by a Bahamian corporation which also provided sewing services. The Commissioner attempted to hold the taxpayer to its representations to the Philippine authorities, regarding the mark-up on

${ }^{89}$ Ibid. 448-9. ${ }_{94}^{90}$ Ibid. 449. $\quad 91$ Ibid. $\quad{ }^{92} 55$ T.C. 928 (1970).

93 Ibid. 993. 94 Ibid. 994-5.

95 Ibid. 997-8. The PPG Industries case is significant in two other respects: it represents an early attempt by the Commissioner to deviate from the ALS and to use industry statistics (prefiguring the current Treasury regulations), and it represents an early case of functional analysis and profit split by the court (prefiguring the White Paper).

9660 T.C. 569 (1973). 
its costs for currency control purposes. The Tax Court rejected this argument and held that 'there is nothing in section 482 or the regulations thereunder to indicate that the arm's length standard of section 482 is to be ignored simply because of representations made in foreign countries. ${ }^{\prime 7}$ The court then determined the transfer price on the basis of arbitrary adjustments to an approximate comparable. ${ }^{98}$

Finally, perhaps the greatest triumph for the ALS came in Lufkin Foundry and Machine Co. v. Commissioner. ${ }^{99}$ The case involved transfer pricing between the taxpayer and its WHTC. The taxpayer introduced evidence regarding the reasonableness of its marketing arrangements, and the Tax Court held for it on that basis. ${ }^{100}$ The Commissioner appealed, citing the need to meet the ALS and arguing that no evidence regarding a taxpayer's internal operations could satisfy the standard on its own. ${ }^{101}$ The Fifth Circuit held for the Commissioner, stating that:

No amount of self-examination of the taxpayer's internal transactions alone could make it possible to know what prices or terms unrelated parties would have charged or demanded. We think it palpable that, if the [arm's length] standard set by these unquestioned regulations is to be met, evidence of transactions between uncontrolled corporations unrelated to Lufkin must be adduced in order to determine what charge would have been negotiated for the performance of such marketing services. ${ }^{102}$

The courts came a long way. A mere decade before Lufkin, the Frank court had declared that, contrary to the regulations, the ALS was only one of many possible criteria under section $482 .{ }^{103}$ It then became the sole criterion, set by 'unquestioned' regulations, and any attempt to establish transfer prices without referring to comparables was invalid. Little guidance, however, was given on what to do in the absence of comparables; and in light of his failed attempts in PPG Industries and Ross Gloves to use evidence that was not based on the ALS, the Commissioner may well have wondered whether his victory in Lufkin could turn out to be a pyrrhic one.

Ibid. 599. Note that the ALS has by now, in the view of the Tax Court, been incorporated into the statute. This is also evidenced by a series of related cases in which the Commissioner attempted unsuccessfully to hold the taxpayer to customs valuations. See, e.g., Brittingham v. Commissioner, 66 T.C. 373 (1976), aff'd 598 F.2d 1375 (5th Cir. 1979); Dallas Ceramic Co. v. United States, 74-2 USTC (CCH) 19830 (N.D. Tex. 1974), rev'd 598 F.2d 1382 (5th Cir. 1979).

98 Ross Glove Co., note 96 above, 60 T.C. at 602.

99468 F.2d 805 (5th Cir. 1972).

100 Ibid. 806-7. ${ }^{101}$ Ibid. ${ }^{102}$ Ibid. 808.

${ }^{103}$ See note 46 above and accompanying texts. 


\subsection{Decline (1972-1992)}

The period between 1972 (when Lufkin was decided) and 1992 (when the proposed section 482 regulations were issued) can be described as a gradual realisation by all parties concerned, but especially Congress and the IRS, that the ALS, firmly established by 1972 as the sole standard under section 482, did not work in a large number of cases, and in other cases its misguided application produced inappropriate results. The result was a deliberate decision to retreat from the standard while still paying lip service to it. This process, which began with the 1986 amendments to section 482, was exacerbated by the White Paper in 1988, and culminated in the proposed section 482 regulations of 1992, the temporary section 482 regulations of 1993 , and the final section 482 regulations of 1994, which essentially eliminated the traditional ALS for the great majority of section 482 cases.

The decline of arm's length can be illustrated by comparing major international section 482 cases decided prior to 1973 , with major cases decided after 1973 and prior to 1993. Relative to the cases of the pre-1973 era, comparables were infrequently found in the later cases. ${ }^{104}$

${ }^{104}$ If one takes only the cases surveyed in the White Paper, note 1 above, and the few major cases decided between 1988 and 1992, one finds that up to 1973, the ALS based on comparable transactions was employed in nine of fourteen cases (64\%). From 1974 onward, comparables were found only in four of thirteen major s. 482 cases (31\%). In all of these four cases (Eli Lilly \& Co. v. Commissioner, 856 F.2d 855 (7th Cir. 1988); Paccar, Inc. v. Commissioner, 85 T.C. 754 (1985); U.S. Steel Corp. v. Commissioner, 617 F.2d. 942 (2d Cir. 1980); and Bausch \& Lomb Inc. v. Commissioner, 933 F.2d 1084 (2d Cir. 1991)) the Service argued that the comparable was inappropriate, and in U.S. Steel and Bausch \& Lomb, it attempted to reverse the result in the proposed and temporary regulations. The White Paper cites the following cases decided prior to 1973: National Securities Corp. v. Commissioner, 137 F.2d 600 (3rd Cir. 1943), cert. denied, 320 U.S. 794 (1943); Hall v. Commissioner 294 F.2d 82 (5th Cir. 1961); Nestle Co., Inc. v. Commissioner, 22 T.C.M. 46 (1963); Oil Base, Inc., 362 F.2d 212 (9th Cir. 1966); Johnson Bronze Co., 24 T.C.M. 1542 (1965); Eli Lilly \& Co., 372 F.2d 990 (1967); Young \& Rubicam, Inc. v. United States, 410 F.2d 1223 (1969); U.S. Gypsum Co., 452 F.2d 445 (7th Cir. 1971); Woodward Governor Co., 55 T.C. 56; Baldwin-Lima-Hamilton Corp., 435 F.2d 182 (1970); PPG Industries Inc., 55 T.C. 928 (1970); Lufkin Foundry and Machine Co., 468 F.2d 805 (5th Cir. 1972); Ross Glove Co., 60 T.C. 569 (1973); and R.T. French Co. v. Commissioner, 60 T.C. 836 (1973). The White Paper cites the following cases decided after 1974: Dallas Ceramic Co. v. United States, 598 F.2d 1382 (5th Cir. 1979); Cadillac Textiles, Inc. v. Commissioner, 34 T.C.M. 295 (1975); Edwards v. Commissioner, 67 T.C. 224 (1976); E.I. DuPont de Nemours of Co. v. United States, 608 F.2d 445 (Ct. Cl. 1979); U.S. Steel Corp. v. Commissioner, 617 F.2d 942 (2d Cir. 1980); Hospital Corp. of America v. Commissioner, 81 T.C. 520 (1983); Eli Lilly \& Co. v. Commissioner, 856 F.2d 855 (7th 
The causes for this decline in the application of arm's length are complex, and are discussed more fully in section 3.5. Part of the explanation, of course, is that after the courts accepted the ALS, cases where comparables could easily be found were less likely to get litigated. But the fact that litigation proliferated nonetheless suggests that in too many cases the ALS was not workable. In order to understand why, it is necessary to examine the major section 482 cases from the last two decades. ${ }^{105}$

Consider first some major cases in which a comparable was found. R.T. French Co. v. Commissioner, ${ }^{106}$ decided in 1973, illustrates one type of problem that the IRS encountered in applying arm's length. In French, the taxpayer, a US subsidiary of a UK parent, negotiated a royalty rate for the parent's valuable patented process for producing instant mashed potatoes in 1946, for a twenty-one-year period. This was before the profitability of the process was known and when there was an unrelated 49 per cent minority shareholder in the parent. In 1960, when the minority shareholder had been bought out and the process had proved extremely profitable, the licensing contract was amended, but the royalty rate remained unchanged for the duration of the contract. ${ }^{107}$

Cir. 1988); Ciba-Geigy Corp. v. Commissioner, 85 T.C. 172 (1985); Paccar, Inc. v. Commissioner, 85 T.C. 754 (1985); G.D. Searle \& Co. v. Commissioner, 88 T.C. 252 (1987). Major cases decided between 1988 and the issuance of the proposed regulations in 1992 are Bausch \& Lomb, Inc. v. Commissioner, 933 F.2d 1084 (1989); Sunstrand Corp. v. Commissioner, 96 T.C. 226 (1991); Merck \& Co. Inc. v. United States, 24 Cl.Ct 73, 91-2 USTC 150,456, at 89,736 (1991). Of these cases, comparables were used only in U.S. Steel, Eli Lilly (for one year), Paccar and Bausch \& Lomb.

The White Paper reports that in international examinations generally, 'fourth methods' were used 36 per cent of the time, see White Paper, note 1 above, p. 502, and that other estimates of this figure range from 14 per cent to 47 per cent. Ibid. 463 . However, the most telling number is that in an astounding 91 per cent of the cases examined, the taxpayers did not use comparables in establishing transfer prices. Ibid. 502. See also US General Accounting Office, IRS Could Better Protect U.S. Tax Interests in Determining the Income of Multinational Corporations (1981) pp. 29 (finding that of 403 cases studied, in dollar terms, the CUP method based on direct comparables accounted for only 3 per cent of the adjustments).

105 The following discussion is based on cases decided between 1973 and the issuance of the proposed regulations in 1992. Since 1992, there have been several more s. 482 cases based on the old regulations, and the results have been similar to those described in the text. However, the IRS has been slightly more successful, as the litigating skills utilised in s. 482 cases have improved. See, e.g., Perkin-Elmer Corp. v. Commissioner, 66 T.C.M. (CCH) 634 (1993); Seagate Technology, Inc. v. Commissioner, 102 T.C. 149 (1994); and National Semiconductor Corp. v. Commissioner, 67 T.C.M. (CCH) 2849 (1994).

10660 T.C. 836 (1973). $\quad 107$ Ibid. 838-9. 
The Service argued that unrelated parties would have amended the royalty rate so that it would be commensurate with the income derived from the patent, and that the low rates of the contract resulted in constructive dividends to the UK parent, which should be subject to withholding. ${ }^{108}$ The Tax Court disagreed. It held that the original 1946 contract was negotiated at arm's length because of the 49 per cent minority shareholder in the UK parent: 'The position of [the minority shareholder] in the scheme of things in all likelihood assured the arm's length character of the transaction. ${ }^{109}$ Thereafter, the fact that profitability changed 'in no way detracted from the reasonableness of the agreement when it was made', and there was no basis for a section 482 adjustment 'so long as the "arm's length" test is met. There is no reason to believe that an unrelated party in [the parent's] position would have permitted petitioner to avoid its contractual obligations. 110

French illustrates the fallacy of relying entirely on the arm's length nature of the original contract, when the economic results are clearly disproportionate to the parties' expectations when that contract was signed. The Service found itself in the position of having to argue against the ALS it had espoused for so long, citing as its primary authority a case (Nestle) that was decided in the short interval between Frank and Oil Base, when the standard was not established as the main criterion for section 482. Not surprisingly, the Tax Court found this hard to accept after the Service had worked so hard to establish arm's length as the standard in all section 482 cases. ${ }^{111}$ It took thirteen years and the 1986 Tax Reform Act to reverse the result of French.

U.S. Steel Corp. v. Commissioner ${ }^{112}$ illustrates another type of problem that is recurrent in applying arm's length: the difficulty of comparing intragroup with outside transactions, even when the same product or service is involved. U.S. Steel owned a Liberian subsidiary, Navios, which it used to ship steel from Venezuela to the United States. The prices charged by Navios were set at a level that would make the steel price equal to the price of domestic steel manufactured by U.S. Steel, and the same price was charged by Navios for shipping for unrelated corporations, albeit at much lower quantities. ${ }^{113}$ As a result Navios had high profits which were totally exempt from tax. In Tax Court, the Service successfully upheld its reallocation of US $\$ 52$ million in profits to the taxpayer. ${ }^{114}$

Ibid. 836-7 (citing Nestle Co., Inc. v. Commissioner, 22 T.C.M. (CCH) 46 (1963)) (the Service was in the unusual position of arguing that royalties to a foreign parent were too low).

109 Ibid. 851. ${ }^{110}$ Ibid. 852-4. ${ }^{111}$ Ibid. 849-50.

112617 F.2d 942 (2d Cir. 1980). $\quad{ }^{113}$ Ibid. $945 .{ }^{114}$ Ibid. 942. 
The taxpayer appealed and the Court of Appeals for the Second Circuit reversed. The court held:

We are constrained to reverse because, in our view, the Commissioner has failed to make the necessary showings that justify reallocation under the broad language of section $482 \ldots$ The Treasury Regulations provide a guide for interpreting this section's broad delegation of power to the Secretary, and they are binding on the Commissioner ... [citing the ALS] This 'arm's length' standard ... is meant to be an objective standard that does not depend on the absence or presence of any intent on the part of the taxpayer to distort his income ... We think it is clear that if a taxpayer can show that the price he paid or was charged for a service is 'the amount which was charged or would have been charged for the same or similar services in independent transactions with or between unrelated parties' it has earned the right, under the Regulations, to be free from a section 482 reallocation despite other evidence tending to show that its activities have resulted in a shifting of tax liability among controlled corporations. ${ }^{115}$

The court thus concluded that the only issue was the comparability of Navios' transactions with those of unrelated parties. It held that they were comparable, despite the differences in volume and the assurance of continued service as a result of the parties' relationship, and despite the taxpayer's ability to manipulate the prices of the steel so as to leave a larger profit to the tax exempt shipper. ${ }^{116}$ The court stated that:

Attractive as this argument is in the abstract, it is a distortion of the kind of inquiry the Regulations direct us to undertake. The Regulations make it clear that if the taxpayer can show that the amount it paid was equal to 'the amount which was charged ... for the same or similar services in independent transactions' he can defeat the Commissioner's effort to invoke section 482 against him. ${ }^{117}$

The court rejected the Commissioner's argument that transactions with 'independent' parties are only relevant in a competitive market and not where U.S. Steel had a de facto monopoly, holding that this would impose an 'unfair' burden on the taxpayer. Finally, it addressed the Tax Court's attempt to return to a reasonableness standard:

In at least one portion of Judge Quealy's opinion, however, it appears that the reason he relied upon to hold Navios' charges too high is not at all a matter involving the comparison of rates Steel paid to those paid by other steel companies. He said that what the rates paid by Steel must be measured 
against in order to see if a section 482 reallocation is justified is 'what might be a reasonable charge for a continuing relationship involving the transportation of more than 10 million tons of iron ore per year'. If this is indeed the inquiry, then the fact that other steel companies paid Navios the same rates Steel did is irrelevant. We are constrained to reject this argument. Although certain factors make the operations undertaken by Navios for Steel uniqueat one point, for example, Navios' ore carriers were the largest of their kind in the world - the approach taken by the Tax Court would lead to a highly undesirable uncertainty if accepted. In very few industries are transactions truly comparable in the strict sense used by Judge Quealy. To say that Pittsburgh Steel was buying a service from Navios with one set of expectations about duration and risk, and Steel another, may be to recognize economic reality; but it is also to engraft a crippling degree of economic sophistication onto a broadly drawn statute, which - if 'comparable' is taken to mean 'identical', as Judge Quealy would read it - would allow the taxpayer no safe harbor from the Commissioner's virtually unrestricted discretion to reallocate. $^{118}$

Given the history of the ALS, it is hard to see how the court could have reached a different conclusion; the 'reasonableness' standard used by the Tax Court had, by 1980, been officially pronounced dead for sixteen years. ${ }^{119}$ However, the Service's frustration at being thus hoist by its own petard is understandable, as is its subsequent attempt to reverse U.S. Steel in regulations. ${ }^{120}$ The continued vitality and extensive effect of both French and U.S. Steel was illustrated in one of the major recent section 482 cases, Bausch \& Lomb, Inc. v. Commissioner. ${ }^{121}$ In Bausch \& Lomb, the taxpayer $(B \& L)$ licensed its unique process for manufacturing soft contact lenses to an Irish tax haven manufacturer ( $B \& L$ Ireland) and charged a royalty of 5 per cent. The Irish subsidiary manufactured the lenses for US $\$ 1.50$ each and sold them to the taxpayer for US $\$ 7.50$ each - the same price charged by unrelated parties with much higher manufacturing costs for the same product. ${ }^{122}$

The Commissioner's proposed adjustments included eliminating the royalty (on the theory that B\&L Ireland was a contract manufacturer assured of a market for its sales) but adjusting the income to give $B \& L$ Ireland its costs plus a profit of 20 per cent. ${ }^{123}$ The Tax Court held that

Oil Base, Inc. v. Commissioner, 23 T.C.M. (CCH) 1838, 1845-6 (1964); see notes 58-9 above and accompanying text.

120 See Prop. Treas. Reg. s. 1.482-2(e)(2)(ii); Temp. Treas. Reg. s. $1.482-1 \mathrm{~T}(\mathrm{e})(3)(\mathrm{iii})$; Temp. Treas. Reg. s. 1.482-3T(b)(2)(ii)(B), (iv); Treas. Reg. s. 1.482-1(d)(3)(ii)(C).

12192 T.C. 525 (1989).
122 Ibid. $525,580$.

${ }^{123}$ Ibid. 580-1. 
these adjustments were an abuse of discretion. In an 86-page long opinion it first rejected the Service's 'contract manufacturer' analysis on the grounds that there was no contractual obligation by $\mathrm{B} \& \mathrm{~L}$ to purchase the product (as if such an obligation was needed between related parties!). ${ }^{124}$ Then, the Tax Court held that the transfer price was correct on the basis of the unrelated sales, despite the economic differences (volume differences, integrated business differences, and the fact that B\&L had much lower production costs than its competitors) between the alleged comparables:

We find that use of the comparable uncontrolled price method of determining an arm's length price is mandatory. The third-party transactions identified by petitioner provide ample evidence that the $\$ 7.50$ per-lens price charged by B\&L Ireland is equal or below prices which would be charged for similar lenses in uncontrolled transactions. We place particular reliance on the Second Circuit's opinion in U.S. Steel. To posit that B\&L, the world's largest marketer of soft contact lenses, would be able to secure a more favorable price from an independent manufacturer who hoped to establish a long-term relationship with a high volume customer may be to recognize economic reality, but to do so would cripple a taxpayer's ability to rely on the comparable uncontrolled price method in establishing transfer pricing by introducing to it a degree of economic sophistication which appears reasonable in theory, but which defies quantification in practice. ${ }^{125}$

The court then rejected the argument from disparities of volume and from the taxpayer's lower costs, holding that the US $\$ 7.50$ price was 'a market price' and therefore the taxpayer had 'earned the right to be free of adjustment' under U.S. Steel. ${ }^{126}$ In the second part of its opinion, the Tax Court applied French and held that the subsequent profitability of the intangible was irrelevant for establishing a royalty rate, even though the licensing agreement in Bausch \& Lomb (unlike the one in French) was terminable at will. ${ }^{127}$ Accordingly, the court rejected the taxpayer's 5 per cent and the Service's $27-33$ per cent rates and, since there were predictably no comparables, arbitrarily set its own rate at 20 per cent. ${ }^{128}$

The Commissioner appealed and the Second Circuit affirmed. ${ }^{129}$ It admitted that 'the Commissioner's position is not without force', but held that under the regulations and the ALS, applying the

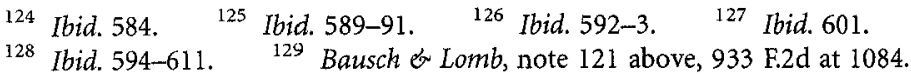


comparable uncontrolled price method was mandatory, even though economic reality may differ:

The position urged by the Commissioner would preclude comparability precisely because the relationship between $\mathrm{B} \& \mathrm{~L}$ and $\mathrm{B} \& \mathrm{~L}$ Ireland was different from that between independent buyers and sellers operating at arm's length. This, however, will always be the case when transactions between commonly controlled entities are compared to transactions between independent entities. ${ }^{130}$

The IRS position would, in effect, 'nullify' the CUP method. The court thus felt compelled to affirm that, under the regulations, as long as the ALS governed, uneconomic results would have to be upheld even though transactions between related parties cannot realistically be compared to arm's length transactions. But if that is the case, why should the ALS apply? ${ }^{131}$

French, U.S. Steel and Bausch \& Lomb illustrate a major problem in applying the ALS: if inexact comparables are used because the market had changed, ${ }^{132}$ or because the relationship between the parties makes for a different nature of transaction, ${ }^{133}$ the ALS leads to results that are completely unrealistic as an economic matter. ${ }^{134}$ Why, then, were the courts in these cases so avid to find that comparables were controlling? The regulations and precedents applying the ALS provide only partial answers. The main reason was the courts' stated awareness of the morass they would be getting into by seeking to determine transfer prices in the absence of comparables. Decisions (not based on comparables) that

${ }^{130}$ Ibid. 1091.

131 The Second Circuit also affirmed the Tax Court's 'best judgment' royalty determination under a 'not clearly erroneous' standard. The Second Circuit's opinion in Bausch o Lomb, as well as the Claims Court's opinion in Merck \& Co. v. United States, $24 \mathrm{Cl}$. Ct. 73 (1991), 91-2 USTC 150,456, in effect declare that the ALS is economically if not legally inapplicable to an integrated multinational. See below.

132 See R.T. French Co., note 106 above, 60 T.C. at 836; Bausch \& Lomb, note 121 above, 933 F.2d at 1084 .

133 See U.S. Steel Corp., note 112 above, 617 F.2d at 942; Bausch \& Lomb, note 121 above, 933 F.2d at 1084.

${ }^{134}$ Even when the comparables are closer, many adjustments are usually needed. In Eli Lilly \& Co. v. Commissioner, 84 T.C. 996, 1176-86 (1985), for the one year in which a comparable existed, the Tax Court discussed the necessary adjustments over 11 pages, and reached the conclusion that a 66 per cent discount from the 'comparable' price was needed! But cf. Paccar, Inc. v. Commissioner, 85 T.C. 754 (1985) (Tax Court accepted the taxpayer's proposed comparable with only minimal adjustments). 
cover hundreds of pages only to reach unpredictable and arbitrary results seem to justify this conclusion.

Cadillac Textiles v. Commissioner ${ }^{135}$ is an early example of the courts' predicament in a domestic section 482 case. The case involved commissions paid by the taxpayer to a related entity for weaving. The taxpayer relied on the comparability of these commissions to those paid to unrelated entities. ${ }^{136}$ The Tax Court, in a memorandum opinion, held that the alleged comparables were dissimilar because of volume differences and because there was no commitment for a continuing relationship - precisely the same factors that should have been applied in U.S. Steel and Bausch of Lomb. ${ }^{137}$ However, having properly struck down the comparables, and having rejected the Commissioner's allocation as 'heavy handed', the court was faced with the necessity of making an arbitrary determination of the transfer price:

Where some allocation is justified, if the respondent fails to follow a reasonable method in making such allocation, the Court must substitute its judgment ... Unfortunately, this places upon the Court the burden of decision without having all the facts ... Looking to the combined profits of both enterprises, and applying [a value added] factor, it is the Court's conclusion that there should be allocated to the petitioner under section $482 \ldots$ the sum of $\$ 100,000$ [instead of $\$ 193,045.37$, as proposed by the Commissioner]. ${ }^{138}$

The Tax Court thus applied a 'profit split', the method later advocated by the White Paper ${ }^{139}$ and ultimately specified in the current regulations. ${ }^{140}$ However, as the round figures indicate, ${ }^{141}$ the result was largely arbitrary. In the absence of any guidance in the regulations, the court had little choice. This explains why other courts were so reluctant to abandon any comparable, if one could be found. ${ }^{142}$

13534 T.C.M. (CCH) 295 (1975).

136 Ibid. 305 (citing Treas. Reg. s. 1.482-2(b)) (defining the arm's length allocation for the performance of services).

137 Ibid. 305-6.

${ }^{138}$ Ibid. 306. ${ }^{139}$ White Paper, note 1 above, p. 490. ${ }^{140}$ Treas. Reg. s. 1.482-6.

141 Cadillac Textiles Inc, note 135 above, 34 T.C.M. at 306.

142 See, e.g., Edwards v. Commissioner, 67 T.C. 224 (1976). In Edwards, another domestic s. 482 case, the Commissioner argued for a profit split, and the Tax Court rejected this suggestion as incompatible with the ALS, but relied on profits from an uncontrolled sale: 'The focus is not, as suggested by respondent, on determining an acceptable or reasonable overall gross profit percentage, but is on determining an arm's length price for the sale or sales in question by using the gross profit percentage established in an uncontrolled sale.' Ibid. 236-7. 
The first major international section 482 case from this period, E.I. DuPont de Nemours o Co. v. United States, ${ }^{143}$ was a major victory for the Service. The facts in DuPont were particularly favourable to the Service, since the taxpayer admitted that it had set transfer prices with its tax haven (Swiss) marketing subsidiary, DISA, with no reference to anything but maximising DISA's profitability. An internal DuPont memo discovered by the Service read:

It would seem to be desirable to bill the tax haven subsidiary at less than an 'arm's length' price because: (1) the pricing might not be challenged by the revenue agent; (2) if the pricing is challenged, we might sustain such transfer prices; (3) if we cannot sustain the prices used, a transfer price will be negotiated which should not be more than an 'arm's length' price and might well be less; thus we would be no worse off than we would have been had we billed at the higher price. ${ }^{144}$

In the face of these facts, the taxpayer attempted to show that DISA met the resale price method of the regulation. The court easily rejected this argument:

We have itemized the special status of DISA - as a subsidiary intended and operated to accumulate profits without much regard to the functions it performed or their real worth - not as direct proof, in itself, supporting the Commissioner's reallocation of profits under Section 482, but instead as suggesting the basic reason why plaintiff's sales to DISA were unique and without any direct comparable in the real world ... the vital prerequisite for applying the resale price method is the existence of substantially comparable uncontrolled resellers ... there is nothing in the record showing the degree of similarity called for by the regulation. ${ }^{145}$

The court, having rejected the taxpayer's comparables (drawn largely from general industry averages and the IRS Sourcebook of Statistics of Income), was faced with the necessity of either determining its own transfer price, or accepting the Service's allocation. Unlike the court in Cadillac Textiles, this court decided to take the easier route and accept the Service's position:

The amount of reallocation would not be easy for us to calculate if we were called upon to do it ourselves, but Section 482 gives that power to the Commissioner and we are content that his amount (totaling some $\$ 18$ million) was within the zone of reasonableness. ${ }^{146}$ 
In determining reasonableness, the court relied on ratios of gross income to total operating costs for functionally similar corporations, and on rates of return for 1,100 corporations in general, ${ }^{147}$ thus prefiguring the methods of the recently issued proposed, temporary and final regulations. ${ }^{148}$ However, there was no suggestion that this reallocation constituted an application of the ALS. The opinion drew a spirited concurrence from Judge Nichols, who pointed out some of the problems with the court's approach:

The evidence referred to supports [the result] in the weakest possible way, [we are] making bricks without straw. Assuming, still, that no formula prescribed by regulation can be used, if the Commissioner adheres in court to his original method, it would seem we would have to affirm him unless we thought his choice of method arbitrary and capricious. It is not surprising, therefore, that taxpayer's able counsel here put all his chips on the regulatory resale price method, to the virtual exclusion of any reliance on any 'fourth method', really a chaos of any and all methods. Whether the involved regulations leave too many cases for the fourth method is a question the court touches on lightly. The congressional request to write regulations to govern these section 482 reallocations is one sentence long: ["]It is believed that the Treasury should explore the possibility of developing and promulgating regulations under this authority [section 482] which would provide additional guidelines and formulas for the allocation of income and deductions in cases involving foreign income.['] Clearly the result of our decision is that this has not been done in respect to the reallocation here involved, and it remains in the almost if not wholly unreviewable discretion of the Treasury, as it was when the suggestion was made. [The Treasury] should not have discretion to decide how much money anyone should have to pay to support the government. ${ }^{149}$

DuPont was the last major international section 482 decision in which the Service was the clear victor. The 1980s, starting with the Second Circuit's reversal in U.S. Steel, saw a series of section 482 related disasters for the IRS. In 1983, for instance, the Tax Court decided Hospital Corp. of America v. Commissioner. ${ }^{150}$ Here, the taxpayer formed a Cayman Islands subsidiary to perform a contract to manage a hospital in Saudi Arabia. The subsidiary (LTD) performed 'minimal' functions, and all the

147 Ibid. 456.

148 Treas. Reg. s. 1.482-5; Temp. Treas. Reg. s. 1.482-5T (1993); Prop. Treas. Reg. s. 1.4822

(f), 57 Fed. Reg. 3571 (30 January 1992).

149 E.I. DuPont de Nemours Co., note 104 above, 608 F.2d at 461-2.

${ }^{150} 81$ T.C. 520 (1983). 
substantial work on the contract was done by the taxpayer. The Commissioner argued that LTD was a sham, or alternatively, that all of its income should be allocated to the taxpayer. ${ }^{151}$ The Tax Court, in an 82page opinion, rejected both arguments. It held that LTD was not a sham because it 'actually carried on some minimal amount of business activity' and had officers and directors who negotiated the contract, even though the same persons were also officers and directors of the taxpayer. ${ }^{152}$ On the section 482 issue, the court held that the Commissioner abused his discretion by the 100 per cent allocation, because this represented a repetition of the 'sham' argument. ${ }^{153}$ Since there were no comparables suggested by any side, the court was forced to make an arbitrary profit split determination:

Even though we have rejected respondent's 100 percent allocation of taxable income from LTD to petitioner, the evidence indicates overwhelmingly that an allocation is necessary and proper in this case. Unfortunately, there is little quantitative evidence in this record upon which we can determine what a reasonable allocation of profits would be. Neither party has been particularly helpful to the Court in this regard. However, we must do the best with what we have. Using our best judgment on the lengthy and inconclusive record before us, we have concluded and found as a fact that 75 percent of the taxable income of LTD in 1973 was attributable to petitioner. ${ }^{154}$

While a 75 per cent allocation may seem favourable to the Service, on the facts of the case, a 100 per cent allocation would have been justified, since LTD, in effect, performed no economic functions whatsoever. Not surprisingly, the proposed regulations attempted to reverse the result in this case. ${ }^{155}$ The next debacle for the Service was Eli Lilly of Co. v. Commissioner, ${ }^{156}$ which resulted in a particularly length Tax Court opinion of 196 pages. Lilly was one of a series of cases concerning transfers, by pharmaceutical giants, of valuable patents developed as a result of extensive domestic research and development in the United States. Thereafter, the patents were transferred on a tax-free basis to Puerto Rican subsidiaries who could reap their rewards and benefit from

151 Ibid. 577. ${ }^{152}$ Ibid. 578-87. ${ }^{153}$ Ibid. 592-5. ${ }^{154}$ Ibid. 596-601.

155 See Treas. Reg. s. 1.482-2(b)(8) (intangible regulations should apply in such cases of services combined with know-how); Preamble to Prop. Treas. Reg. s. 1.482-2(e) (30 January 1992).

15684 T.C. 996 (1985), aff'd in part, rev'd in part and remanded, 856 F.2d 855 (7th Cir. 1988). 
Puerto Rico's tax haven status. As an economic matter, there was no justification for letting the Puerto Rican subsidiary reap the rewards of the research done by the taxpayer without paying any royalty or other consideration for the patents. ${ }^{157}$

The taxpayer organised the subsidiary, Lilly P.R., in 1965, after having developed certain extremely lucrative patented processes. It transferred the patents to Lilly P.R., which relied on the patents to become the sole manufacturer of two drugs, Darvon and Darvon-N. Lilly P.R. then sold these drugs to the taxpayer, who in turn marketed the products throughout the United States. ${ }^{158}$ The Commissioner reallocated the entire income from the patents to the taxpayer, arguing that Lilly P.R. was a mere contract manufacturer and that its ownership of the intangibles should be disregarded. The Tax Court rejected this approach, holding that the legal ownership of the intangibles could not be disregarded. ${ }^{159}$ It also rejected the Commissioner's argument that the separation of income from expenses to create the patents led to a distortion, mainly because the expenses were incurred largely in the 1950s, long before the transfer, and had been recovered previously. ${ }^{160}$

The Tax Court then reached the issue of proper transfer pricing under the ALS. The prices paid by the taxpayer were such that it could not use the profits to fund its current R\&D. The Tax Court held that this was unacceptable: 'It is inconceivable that petitioner, negotiating at arm's length, would have transferred valuable income-producing intangibles without a royalty, lump-sum payment, or other agreement that would enable petitioner to continue its general research and development activities.' ${ }^{161}$ Thus, some section 482 allocation was necessary. However, as the drugs had been patented for two of the years in question, there were no comparables. Hence, the three regular methods (CUP, cost plus and resale price) were inapplicable. Having rejected both parties' expert witnesses, the court was obliged to determine an arbitrary 'reasonable profit split' based on the functions performed by the parties. Under the profit split, the court allocated to Lilly P.R. 100 per cent of manufacturing costs plus location savings, and 55 per cent of its income from marketing intangibles. ${ }^{162}$ The result was a reallocation to the taxpayer

157 See generally, I. T. Hexner and G. P. Jenkins, 'Puerto Rico and Section 936: A Costly Dependence' (1995) 10 Tax Notes Int'l 235 (discussing the relationship between transfer pricing and tax benefits for subsidiaries of US corporations, operating in Puerto Rico).

159 Ibid. $1123 .{ }^{160}$ Ibid. $1126 .{ }^{161}$ Ibid. 1130.

162 Ibid. 1151, 1167. 
of US $\$ 23$ million for the 1971-2 tax years, instead of US \$53 million as advocated by the Commissioner. ${ }^{163}$

Both parties appealed. The Court of Appeals for the Seventh Circuit reached a result which was even more favourable to the taxpayer. ${ }^{164} \mathrm{It}$ rejected the Tax Court's argument that Lilly would not have transferred the patents to an unrelated party without getting enough consideration to fund its ongoing $R \& D$, holding that the stock of Lilly P.R. received by the taxpayer, together with distribution rights and technical assistance contracts, constituted sufficient consideration. ${ }^{165}$ The Court of Appeals, nevertheless, approved the profit split method as 'not unreasonable', but remanded for an adjustment that did not require Lilly P.R. to participate in the taxpayer's R\&D expenses. ${ }^{166}$ It took the 1986 amendments to section 482 to reach a more economically reasonable result. ${ }^{167}$

The Service fared even worse in G.D. Searle \& Co. v. Commissioner, ${ }^{168}$ the companion case to Lilly. Like Lilly, Searle transferred drug patents to its Puerto Rican subsidiary (SCO) for no consideration; however, SCO subsequently manufactured and sold the drugs to unrelated parties so no transfer price issue was involved. The Tax Court rejected the Service's attempt to ignore the transfer of the intangibles and allocate the income to the taxpayer by treating SCO as a contract manufacturer. ${ }^{169}$ The court then held that some consideration for the transfer was necessary as the intangibles accounted for 80 per cent of the taxpayer's income and transferring the patents to an unrelated party solely for stock would be 'the height of corporate mismanagement. ${ }^{\text {. }}{ }^{70}$ As there were no comparables, the Tax Court was required to use its arbitrary 'best judgment' and allocated to the taxpayer US \$29 and US \$34 million for the two years in question ( 25 per cent of SCO's total net sales), compared to the US $\$ 92$ and US $\$ 110$ million sought by the Service. ${ }^{171}$ Significantly, the court did not attempt to characterise this result as the product of an arm's length allocation; instead, the court reasoned 'arm's length consideration for section 482 purposes is that which results in a clear reflection of income. ${ }^{172}$ This remarkable tautology (the standard for clear reflection is arm's length, and arm's length is whatever results in clear reflection) marks a low point in the courts' attempts to apply the ALS in the absence of arm's length transactions.

163 Ibid. 1107, 1167. ${ }^{164}$ Eli Lilly o Co., note 104 above, 856 F.2d at 855.

165 Ibid. 863. ${ }^{166}$ Ibid. 871-2. ${ }^{167}$ See discussion below.

16888 T.C. 252 (1987). $\quad{ }^{169}$ Ibid. 366-7. ${ }^{170}$ Ibid. $370 . \quad{ }^{171}$ Ibid. 376.

172 Ibid. 375. 
The Service fared equally badly in its attempts to avoid the results of its own regulations in Ciba-Geigy Corp. v. Commissioner, ${ }^{173}$ an inbound section 482 case. The case involved the appropriate rate of royalty to be paid by the taxpayer to its Swiss parent under an exclusive licence in which all the significant R\&D had been done at the parent level. The Service argued the taxpayer was engaged in a joint venture with the parent and should have paid a lower royalty than 10 per cent or, alternatively, the arm's length rate was lower. The taxpayer argued for a higher royalty than 10 per cent. The Tax Court rejected the Service's attempts 'to deflect the thrust of his own "transfer or use of intangible property" regulations ... which to respondent's discomfiture fit this case like a glove. ${ }^{174}$ Having rejected both parties' proposed comparables (because of different degrees of risk and the uniqueness of the relationship), the court held that the 10 per cent rate was reasonable, based on the 'substantial negotiations' between the related parties ${ }^{175}$ and the testimony of an unrelated party who would have paid between 10 and 12.5 per cent for a non-exclusive licence. ${ }^{176}$ The Service's position in this case seems unreasonable, and a higher royalty rate should have been allowed, based on the unexpected profitability of the patent, the difference between exclusive and non-exclusive licences, and the fact the parent performed the R\&D.

The same arbitrariness and disregard for economic reality persists in two other recent section 482 cases which were decided, like Bausch \& Lomb, after the publication of the White Paper: Sundstrand Corp. v. Commissioner ${ }^{177}$ and Merck o Co. Inc. v. United States. ${ }^{178}$ Sundstrand involved the licence of valuable manufacturing technology for aircraft spare parts to the taxpayer's Singapore subsidiary which in turn sold the parts to the taxpayer for distribution. The Service again attempted to apply its contract manufacturer analysis which seems appropriate because the subsidiary did not develop the product and was guaranteed, although not formally, to sell its products to the taxpayer (the airlines actually refused to buy from the subsidiary directly). The Tax Court, relying on Bausch \& Lomb, rejected this analysis and also rejected all of the taxpayer's and the Service's proposed comparables. ${ }^{179}$ Having criticised the parties for their 'contentiousness' and lack of cooperation, ${ }^{180}$ the court made its own 'best estimate' of the appropriate transfer price,

\footnotetext{
17385 T.C. 172 (1985). $\quad{ }^{174}$ Ibid. $222 . \quad{ }^{175}$ Ibid. $237 . \quad{ }^{176}$ Ibid. 226.

17796 T.C. 226 (1991). $\quad{ }^{178} 24$ Cl. Ct. 73 (1991).

179 Sundstrand, note 104 above, 96 T.C. at 356-7. 180 Ibid. 374.
} 
relying on the discounts given by the taxpayer on other products and on its representations to US Customs. ${ }^{181}$ These bases seem both arbitrary and unrelated to the issue facing the court. With respect to the royalty, the court again rejected all comparables and arbitrarily fixed a rate of 10 per cent. $^{182}$

Merck \& Co. Inc. v. United States, ${ }^{183}$ a case similar to G.D. Searle, is yet another recent section 482 defeat for the Service. In Merck, the taxpayer developed drugs and transferred the patents to its Puerto Rican subsidiary, MSDQ, which manufactured and sold the drugs to unrelated parties. The Service argued MSDQ should have paid the taxpayer a royalty for its $\mathrm{R} \& \mathrm{D}$ and marketing assistance. The Claims Court rejected the Service's position in its entirety, and ordered a refund to the taxpayer of US $\$ 5$ million, plus interest. ${ }^{184}$ The court recognised the location of the patents within the group had no business consequences, ${ }^{185}$ but held the transfer of the intangibles valid. ${ }^{186}$ The court found no continued royalty was required since the costs of $R \& D$ had been recovered before the transfer. ${ }^{187}$ The court further found that the taxpayer did not provide any marketing services to MSDQ, despite the overlap of officers and directors and the functional integration between the two companies. ${ }^{188}$ The court recognised, as an economic matter, that its decision was untenable, but felt obliged to make it in view of the 'all or nothing' positions of the parties.

For tax years 1972 through 1976, MSDQ reported taxable income that totalled US $\$ 181,802,000$. Federal income tax paid was US $\$ 657,000$. The pricing process that produces such disparity between costs of production and end-product prices, and permits the accumulation of retained earnings that amount to 98.82 percent of all reported taxable income, may be economically unjustified or socially unacceptable. Such results may underscore infirmities in the controls to be expected in regulated pharmaceutical markets. Such results do not establish a distortion of income as to MSDQ. Such problems cannot be addressed through section 482 , under the statute and regulations as presently written. ${ }^{18}$

Thus, the court ignored the analysis in G.D. Searle, that no party would transfer the intangibles to an unrelated party without

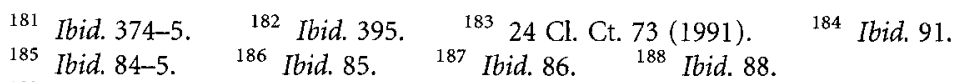

189 Ibid. 91. For another example of a court, this time the Tax Court, interposing its judgment over that of the Service in an R\&D context, see Westreco, Inc. v. Commissioner, 64 T.C.M. (CCH) 849 (1992). 
consideration. ${ }^{190}$ Although this seems facially unjustifiable, any attempt to find the proper royalty rate (if required, since there could be no comparables) in the absence of 'some formula or method' ${ }^{191}$ must have appeared equally frustrating to the court. What makes Merck remarkable is that arm's length analysis did not enter the court's opinion at all. The only issue discussed was whether Merck performed R\&D and marketing functions for MSDQ, not whether it would have transferred the patents to an unrelated party. By ignoring arm's length, the Claims Court in effect held the standard is inapplicable to an integrated multinational enterprise like Merck, which can shift its intangibles around as it wishes. ${ }^{192}$

Merck and Bausch \& Lomb thus mark the end of a process in which the ALS became increasingly irrelevant to section 482 cases. The result demonstrated that the then governing statute and regulations required changing to reflect the economic reality of multinationals. Since 1982, this task has been undertaken by Congress and the Service in the recent proposed, temporary and final regulations, leading to the abandonment of the traditional and narrow ALS for the vast majority of section 482 cases.

\subsection{Fall (1992-1994)}

In 1982, Congress began closing some of the loopholes that were evident in the section 482 cases. The Tax Equity and Fiscal Responsibility Act (TEFRA) altered the treatment of income attributable to intangible assets owned or leased by possessions corporations benefitting from

190 G.D. Searle, note 104 above, 88 T.C. at 370

191 Merck, note 178 above, $24 \mathrm{Cl}$. Ct. at 86.

192 In Proctor of Gamble Co. v. Commissioner, 95 T.C. 323 (1990), aff'd, 961 F.2d 1255 (6th Cir. 1992), the Tax Court reversed the Commissioner's s. 482 royalty allocation from P\&G Spain to its Swiss parent, which had provided P\&G Spain with substantial technical assistance, because $\mathrm{P} \& \mathrm{G}$ Spain was forbidden from paying royalties under Spanish law. This case illustrated the irrelevance of the ALS; clearly, no unrelated party would have provided the assistance to P\&G Spain knowing it could not be paid under Spanish law. The issue under s. 482 should be the economic allocation of income, not whether a royalty could by paid. For a similar result under even more egregious circumstances, see Exxon Corp. v. Commissioner, 66 T.C.M. (CCH) 1707 (1993), where the Tax Court refused to allow the Service to allocate intercompany oil sales between Exxon subsidiaries based on Saudi Arabian price controls set, at the time, below the prevailing market price. Ibid. 1760. Exxon thus escaped the effect of the price restrictions on its income allocation despite demonstrations made by the Service that Exxon had flouted those restrictions. Ibid. 1752-60. 
section 936 of the Code. TEFRA amended section 936 to provide that such income would be treated as income of the corporation's US shareholders unless the corporation elected to make cost sharing payments to its parent or to split the profit from products produced in the possession of the parent on an equal basis. ${ }^{193}$ In passing TEFRA, Congress sought to redress the distortion of income resulting from the separation of $R \& D$ activity and the income derived from the intangible. ${ }^{194}$ Thus, the specific Puerto Rican affiliate problem of Lilly, G.D. Searle and Merck was addressed, but only for post-1982 transfers with no inference regarding prior law.

The next step was taken in the Deficit Reduction Act of 1984, which amended section 367 (d) to treat a tax-free transfer of intangibles to related foreign corporations as a sale of the intangible for annual payments over the useful life of the property contingent on its productivity, use or disposition. ${ }^{195}$ However, no inference was intended for licences of intangibles, which continued to be governed by section 482 . By 1985, Congress realised U.S. Steel and Lilly indicated something should be done about the general application of section 482 of the Code, beyond the specific issues of Puerto Rican corporations or transfers to foreign affiliates. The House Report on House Bill 3838 states the problem as follows:

Many observers have questioned the effectiveness of the 'arm's length' approach of the regulations under section 482 . A recurrent problem is the absence of comparable arm's length transactions between unrelated parties, and the inconsistent results of attempting to impose an arm's length concept in the absence of comparables.

A fundamental problem is the fact that the relationship between related parties is different from that of unrelated parties. Observers have noted that multinational companies operate as an economic unit, and not 'as if' they were unrelated to their foreign subsidiaries. In addition, a parent corporation that transfers potentially valuable property to its subsidiary is not faced with the same risks as if it were dealing with an unrelated party. Its equity interest assures it of the ability ultimately to obtain the benefit of future anticipated or unanticipated profits, without regard to the price it sets. The relationship similarly would enable the parent to adjust its arrangement each year, if it wished to

193 IRC s. $936(\mathrm{~h})(5)$.

194 Joint Comm. on Taxation, 97th Cong., 2d Sess., General Explanation of the Revenue Provisions of the Tax Equity and Fiscal Responsibility Act of 1982, 82-96 (Comm. Print 1983).

195 IRC s. $367(\mathrm{~d})(2)(\mathrm{A})$. 
do so, to take account of major variations in the revenue produced by a transferred item.

Certain judicial interpretations of section 482 suggest that pricing arrangements between unrelated parties for items of the same apparent general category as those involved in the related party transfer may in some circumstances be considered a 'safe harbor' for related party pricing arrangements, even though there are significant differences in the volume and risks involved, or in other factors. See, e.g., United States Steel. While the committee is concerned that such decisions may unduly emphasize the concept of comparables even in situations involving highly standardized commodities or services, it believes that such an approach is sufficiently troublesome where transfers of intangibles are concerned that a statutory modification to the intercompany pricing rules regarding transfers of intangibles is necessary. ${ }^{196}$

The specific solution proposed by the House bill, however, was relatively narrow. It would have added the following sentence to section 482: "in the case of any transfer (or license) of intangible property (within the meaning of section $936(\mathrm{~h})(3)(\mathrm{B}))$, the income with respect to such transfer or license shall be commensurate with the income attributable to the intangible. ${ }^{197}$ Other than rejecting the approaches of French and U.S. Steel, no attempt to modify section 482 more extensively along the lines suggested in the House Report was forthcoming.

Nevertheless, it is noticeable that the House did not pretend that the 'commensurate with income' standard was compatible with the ALS. The Report states the transferor of intangibles in a multinational was looking to its equity investment, 'rather than to "arm's length" factors', to recuperate its cost ${ }^{198}$ and that industry norms or other unrelated party transactions do not provide a safe harbor minimum payment for related party intangible transfers. ${ }^{199}$ Thus, even if a perfect comparable could be found in which the same intangible was transferred to an unrelated party in the same circumstances for a fixed royalty rate, the provision would still require the allocation of 'super-royalties' to a related party transferor.

The conference agreement on the Tax Reform Act of 1986 followed the House bill except for the expansion of the 'commensurate with income'

196 H.R. Rep. No. 426, 99th Cong., 1st Sess. 423-4 (1985) (footnote omitted).

197 H.R. 3838, 99th Cong., 1st Sess. (1985). A similar 'commensurate with income' standard was applied to s. $367(\mathrm{~d})$ transfers of intangibles and to s. 936(h) cost sharing payments.

198 H.R. Rep. No. 426 at $424 . \quad 199$ Ibid. 425. 
provisions to apply to inbound as well as outbound transfers ${ }^{200}$ such as the transfer in Ciba-Geigy. However, the report added the following significant language:

The conferees are also aware that many important and difficult issues under section 482 are left unresolved by this legislation. The conferees believe that a comprehensive study of intercompany pricing rules by the Internal Revenue Service should be conducted and that careful consideration should be given to whether the existing regulations could be modified in any respect. ${ }^{201}$

In light of this language, the report should be seen as an invitation to the Service to shift the focus of the regulations away from the ALS. The result of this invitation was the 1988 White Paper, ${ }^{202}$ the 1992 proposed regulations, ${ }^{203}$ the 1993 temporary regulations, ${ }^{204}$ and the 1994 final regulations under section 482 of the Code. ${ }^{205}$

In discussing the White Paper, it is necessary to distinguish between what it does and what it says it does. First, the White Paper does contain an excellent analysis of the evolution of the statute, the regulations, and the case law under section 482 of the Code, ${ }^{206}$ as well as an overview of the Service's experience in administering the law and regulations. ${ }^{207}$ The analysis suggests that the regulations rely too heavily on finding comparables, ${ }^{208}$ that the case law indicates that the regulations 'fail to resolve the most significant and potentially abusive fact patterns, ${ }^{209}$ and that the 'fourth method' developed in the courts has been inadequate. ${ }^{210}$

After explaining the 1986 changes, ${ }^{211}$ the White Paper reaches the heart of the matter: determining what method should apply to section 482 issues in the absence of comparables. It rejects the applicability of safe harbours because they will only serve as a 'floor' for taxpayers unable to obtain better results otherwise. ${ }^{212}$ The White Paper instead A.N. 4075, 4725. The conference also adopted a Senate provision, enacted as s. 1059A of the Code, which aimed to prevent the disparities between high transfer prices and low custom valuations at issue in Brittingham v. Commissioner, 598 F.2d 1375 (5th Cir. 1979). H.R. Conf. Rep. No. 841 at II-638, reprinted in U.S.C.C.A.N. at 4726.

hite Paper, note 1 above.

203 Prop. Treas. Reg. s. 1.482, 57 Fed. Reg. 3571 (30 January 1992).

204 Temp. Treas. Reg. s. 1.482.p. Treas. Reg. s. $1.482 \mathrm{~T}$ (1993).

205 Treas. Reg. s. 1.482. ${ }^{206}$ White Paper, note 1 above, pp. 459-61.

207 Ibid. pp. 461-5. ${ }^{208}$ Ibid. pp. 464-5. ${ }^{209}$ Ibid. pp. 466-8.

210 Ibid. pp. 469-71. ${ }^{211}$ Ibid. pp. 472-80. ${ }^{212}$ Ibid. p. 481. 
suggests two methods based on determining appropriate returns from a functional analysis of the parties' respective economic contributions. ${ }^{213}$ The first or 'basic' method applies when one party does not use significant intangibles of its own. ${ }^{214}$ The economic functions of that party are analysed and appropriate rates of return are identified based on the rates of return of unrelated parties performing similar activities and assuming similar risks. ${ }^{215}$ The residual is then assigned to the other party. $^{216}$

The second or 'profit split' method applies when both parties perform complex economic functions, bear significant economic risks, and use significant self-developed intangibles. ${ }^{217}$ After applying the basic method to the measurable assets of both parties, the residual is allocated between them by splitting the profits based on the relative values of each party's intangibles. ${ }^{218}$ The White Paper acknowledges that 'splitting the intangible income in such cases will largely be a matter of judgment.'219

This is what the White Paper proposes. The Paper, however, also has another agenda: to portray its suggested methods as compatible with the traditional ALS. ${ }^{220}$ This agenda developed because of the strong objections by our trading partners to the language contained in the 1986 legislative history advocating the abandonment of the ALS. ${ }^{221}$ Thus, as we saw above, the White Paper recommends that the United States continue to adhere to the ALS. ${ }^{222}$ Furthermore, the methods summarised above (including profit split) were given the name 'basic arm's length return method' (BALRM). ${ }^{223}$ Finally, the White Paper contains one chapter devoted to demonstrating the compatibility of the 'commensurate with income' standard and the BALRM method with the ALS, ${ }^{224}$ one chapter defending the ALS on economic grounds, ${ }^{225}$ and an appendix attempting to demonstrate that other countries use methods which are similar to BALRM. ${ }^{226}$

The White Paper also contains one real concession to the ALS in that it permits taxpayers to avoid periodic adjustments to a royalty rate for intangibles if they can find a comparable lacking such adjustments. ${ }^{227}$ This provision flies in the face of the statutory language and the

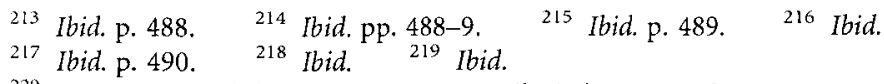

220 See Loengard, 'The Section 482 Pot Boils On', note 17 above.

221 White Paper, note 1 above, p. $475 .{ }_{222}$ Ibid. ${ }_{223}^{22}$ Ibid. p. 488.

${ }^{224}$ Ibid. pp. 475-7. ${ }^{225}$ Ibid. pp. 483-5. ${ }^{226}$ Ibid. app. C. ${ }^{227}$ Ibid. pp. 477-8. 
legislative history of the 1986 amendments, ${ }^{228}$ but the Treasury presumably felt it could not claim to be adhering to the ALS without allowing taxpayers to use comparables if they found them. Indeed, under the White Paper's proposed 'clear and convincing evidence' standard, such comparables in practice will be hard to find. ${ }^{229}$ Whether the BALRM itself is compatible with the ALS depends upon which definition of the ALS is used. The White Paper relies on the 1979 OECD Report on transfer pricing, which permits 'some regard to the profits of the relevant [multinational enterprise]' in determining transfer prices in the absence of comparables. ${ }^{230}$ However, this language falls far short of endorsing the use of either the profit split method advocated by the White Paper or the industry average rates of return. ${ }^{231}$

It is difficult to see in what way the BALRM can meaningfully be called an ALS method in the traditional sense. First, since BALRM by definition can only be applied in the absence of comparables, it falls outside the traditional definition of the ALS, which relies on comparables. Thus, BALRM can only be called an 'arm's length method' if the definition of what constitutes 'arm's length methods' is expanded to include any method that reaches results that are the same as those that would have been reached by unrelated parties. If this is the definition, then 'arm's length' includes the entire transfer pricing continuum, including formulary apportionment, because even pure formulary apportionment may, in appropriate cases, reach the same results as would have been reached by unrelated parties dealing at arm's length.

Second, even if one assumes arm's length dealings proceed from such a functional analysis as envisaged by the BALRM, such an analysis could never lead the parties to a definite fixed transfer price. As Langbein has argued, it could only lead to a range between the minimum the selling party could expect to get based on its costs and the maximum the buying party would be willing to pay based on its resale price. In most related-party contexts, there will be a residual profit not allocable to any

${ }^{228}$ See note 195-6 above and accompanying texts.

229 White Paper, note 1 above, pp. 477-8.

${ }^{230}$ Organization for Economic Co-operation and Development, Transfer Pricing and Multinational Enterprises (1979) ('OECD Report'), p. 52.

231 Ibid. p. 54 ('The profit comparison approach thus remains more in the nature of an indication that the consideration charged for the use of intangible property may or may not be reasonable.'); see also, ibid. p. 52 ('It is considered that it is unlikely to be possible to construct any standard rates.... as even within a given sector of industry it is extremely difficult to discern any typical rate or range of rates.'). 
constituent member, but rather to the existence of the overall organisation. ${ }^{232}$ Thus, unlike a comparable with a fixed price, applying the BALRM between unrelated parties, at best, could lead to a range of acceptable transfer prices. However, the disparity between one end of the range (advocated by the taxpayer) and the other (advocated by the Service) could still be immense. Furthermore, the disparity can only be resolved by applying profit split methods which do not depend on comparables and, hence, fall outside the traditional ALS.

Thus, the true message of the White Paper was that the traditional ALS could not be applied to the majority of section 482 cases because no comparables could be found. What the White Paper instead achieved was to substitute an expanded definition of the ALS for the traditional one: ALS was now understood to include not only CUP, cost plus and resale price but also the rest of the transfer pricing continuum, up to and including profit split, as long as the results reached were compatible with arm's length results. This expansion of the scope of arm's length was the major achievement of the White Paper and constituted a revolution in the United States' approach to transfer pricing. The full fruits of such revolution can be seen in the 1994 final regulations. ${ }^{233}$

The methods that the White Paper suggested as a replacement for the traditional ALS, however, have at least two flaws which have been pointed out repeatedly since $1988 .{ }^{234}$ First, BALRM analysis is extremely complicated and requires massive input by economists and accountants, as well as access to a large fund of not easily available information. ${ }^{235}$ Second, even where the method is applied correctly, it still leaves a substantial residual to be split in many cases, and the White Paper provided no guidance on the ways to split it. The BALRM was thus unlikely to reduce the amount of section 482 litigation or the length of the ensuing opinions because the economists of the Service and the taxpayer predictably differ. When millions of dollars are involved, as is

232 See Langbein, 'The Unitary Method and the Myth of Arm's Length', note 17 above, 654-5; S. I. Langbein, 'Langbein Blasts Arm's Length Method as Unworkable', Tax Analysts Highlights and Documents, 24 August 1990. See also discussion below (analysing the implications of this 'continuum price problem').

233 See Treas. Reg. s. 1.482-6. See also notes $234-52$ below.

${ }^{234}$ See, e.g., R. L. Kaplan, 'International Tax Enforcement and the Special Challenge of Transfer Pricing', (1990) U Ill. L Rev. 299; R. T. Rapp, 'Pitfalls in the BALRM' (1990) 49 Tax Notes 703 (arguing the standards of the BALRM are not easily met in the real world).

235 See, e.g., Rapp, ibid. 706-7. 
the case in most major section 482 cases, the matter is likely to end up in court. In fact, functional analysis was included in the IRS manual and applied before 1988, with no discernible lessening of the section 482 litigation mess. ${ }^{236}$

By 1992, these drawbacks of BALRM persuaded the Service it could not be applied in practice. As a result, when, in accordance with the 1986 legislative history, the proposed regulations came out in January 1992, they made no attempt to implement the White Paper. The Preamble to the proposed regulations states that:

Many comments on the White Paper criticised the prominent role given
to BALRM, arguing that BALRM would be difficult to apply because the
information BALRM required generally would not be available, would be
unfair to corporations whose rates of return vary considerably from the
average, and would allocate too much income to U.S. entities. The Service
also was urged to assign a greater role to inexact comparable transactions
and to reconsider the use of safe harbor rules. These comments were
taken into account in the development of the three pricing methods
described in these proposed regulations.

Instead of BALRM, the proposed regulations introduced the 'comparable profit interval' (CPI) method, ${ }^{238}$ which represented another step towards the demise of the traditional ALS as the guiding standard for applying section 482 of the Code.

The proposed regulations were divided into three parts: intangibles, tangibles and cost sharing. In the case of transfers of intangibles through transfers of tangibles or services, the intangible rules applied if the income attributable to the intangible was 'material' in relation to the income attributable to the tangible property or services. ${ }^{239}$ In the case of intangibles, when a strictly defined 'matching transaction' involving the same intangible under the same or substantially similar economic conditions and contractual terms was lacking, ${ }^{240}$ the next method in order of priority was the 'comparable adjustable transaction' (CAT) method. ${ }^{241}$ Under the CAT method, the arm's length consideration was determined 'by reference to the consideration charged in an

\footnotetext{
${ }^{236}$ See White Paper, note 1 above, p. 464.

237 Preamble to Prop. Treas. Reg. s. 1.482, 57 Fed. Reg. 3571, 3572 (30 January 1992).

238 Prop. Treas. Reg. s. 1.482(f), 57 Fed. Reg. 3571, 3586 (30 January 1992).

239 Prop. Treas. Reg. s. 1.482-2(d)(1)(iii), 57 Fed. Reg. 3571, 3579 (30 January 1992).

240 Prop. Treas, Reg. s. 1.482-2(d)(3), 57 Fed. Reg. 3571, 3580 (30 January 1992).

241 Prop. Treas. Reg. s. 1.482-2(d)(2)(iii), 57 Fed. Reg. 3571, 3579 (30 January 1992).
} 
uncontrolled transfer involving the same or similar intangible under adjustable economic conditions and contractual terms. ${ }^{242}$ To be considered adjustable, the contractual terms and economic conditions must be sufficiently similar such that the effect of any material differences can be determined with reasonable accuracy; ${ }^{243}$ however, even if all the other conditions for applying the CAT method are met, 'an uncontrolled transfer will not meet the standards [of the CAT method] if the consideration determined by reference to that transfer results in a level of operating income for the tested party ... that is outside of the comparable profit interval.'244

In the case of transfers of tangible property, the first method to be applied was the CUP method. ${ }^{245}$ Under the CUP method, the consideration for tangible property was determined by considering uncontrolled transfers of the same or similar physical property in the same or similar circumstances if any differences could be reflected by a reasonable number of price adjustments. ${ }^{246}$ The CUP method was the only method for tangibles not subject to verification by means of the CPI. ${ }^{247}$ When the CUP method was unavailable, other methods such as resale price, cost plus or 'fourth method' could be used, but the results from these methods were all subject to testing under the CPI and the ultimate method used was supposed to reach results at the 'most appropriate point' within the CPI. ${ }^{248}$

The CPI itself was constructed in a series of steps. First, the tested party was selected. ${ }^{249}$ Second, the 'applicable business classification' of the tested party was determined on the basis of the businesses whose operations most closely corresponded to the tested operations involving related parties. ${ }^{250}$ Third, constructive operating incomes were derived by applying profit level indicators from a selection of uncontrolled taxpayers in the applicable business classification to financial data of the tested operations. ${ }^{251}$ These profit level indicators included the rate of return on

242 Prop Treas. Reg. s. 1.482-2(d)(4)(i), 57 Fed. Reg. 3571, 3581 (30 January 1993).

243 Prop. Treas. Reg. s. 1.482-2(d)(4)(iii), 57 Fed. Reg. 3571, 3582 (30 January 1992).

244 Prop. Treas. Reg. s. 1.482-2(d)(4)(i).

245 Prop. Treas. Reg. s. 1.482-2(e)(1)(ii), 57 Fed. Reg. 3571, 3586 (30 January 1992).

246 The CUP method described was a holdover from Treas. Reg. s. 1.482-2(e)(2)(ii), which was in force during the promulgation of the proposed regulations.

247 Prop. Treas. Reg. s. 1.482-2(e)(1)(iii), 57 Fed. Reg. 3571, 3586 (30 January 1992).

248 Prop. Treas. Reg. s. 1.482-2(e)(1)(iii)-(iv), 57 Fed. Reg. 3571, 3586 (30 January 1992).

249 Treas. Reg. s. 1.482-2(f)(4), 57 Fed. Reg. 3571,3587 (30 January 1992).

250 Prop. Treas. Reg. s. 1.482-2(f)(5), 57 Fed. Reg. 3571, 3587 (30 January 1992).

251 Prop. Treas. Reg. s. 1.482-2(f)(6), 57 Fed. Reg. 3571, 3587 (30 January 1992). 
assets, ratio of operating income to sales, and profit splits. Fourth, the CPI was determined on the basis of profit level indicators on the basis of complex statistical techniques. ${ }^{252}$ Fifth, the 'most appropriate point' in the CPI was determined on the basis of other statistical techniques. ${ }^{253}$ Finally, the transfer price was determined so as to produce operating income for the tested party which equalled the constructive operating income corresponding to the most appropriate point in the CPI. ${ }^{254}$ In general, the CPI was to be constructed based on actual, rather than projected, results from the three-year period beginning with the year prior to the one under review. ${ }^{255}$

Is the CPI method of the proposed regulations compatible with the traditional ALS? As our trading partners promptly pointed out, the answer is no, ${ }^{256}$ even under the Treasury's own definition of what constitutes an ALS method. ${ }^{257}$ This definition of an ALS method was based on the definition offered in a 1979 OECD Report which endorsed the ALS and explicitly rejected formulary approaches for allocating profits between related enterprises as 'necessarily arbitrary'. ${ }^{258}$ It accepted, however, the possibility that in seeking to arrive at an arm's length price in a range of transactions, some regard to the total profits of the relevant [multinational enterprise] may ... be helpful, as a check on the assessment of the arm's length price.'259

As the White Paper recognised, the OECD Report endorsed methods which consider the profits of the related enterprises in making arm's length determinations. ${ }^{260}$ The CPI method, on the other hand, looked exclusively at the profits of other taxpayers to determine the proper allocation within the controlled group. ${ }^{261}$ The CPI then judged the results of any method of allocation which, in the case of intangibles, did not meet strict standards of comparability as a 'matching transaction,' 62 or, in the case of tangibles, was not based on a 'comparable uncontrolled price.' ${ }^{263}$

\footnotetext{
252 Prop. Treas. Reg. s. 1.482-2(f)(7), 57 Fed. Reg. 3571, 3589 (30 January 1992).

253 Prop. Treas. Reg. s. 1.482-2(f)(8), 57 Fed. Reg. 3571, 3590 (30 January 1992).

254 Prop. Treas. Reg. s. 1.482-2(f)(9), 57 Fed. Reg. 3571, 3590 (30 January 1992).

255 Prop. Treas. Reg. s. 1.482-2(f)(2), 57 Fed. Reg. 3571, 3587 (30 January 1992).

256 See note 265 below and accompanying texts.

257 See White Paper, note 1 above, p. 476.

258 OECD Report, note 230 above, pp. 14-15. $\quad{ }^{259}$ Ibid. p. 150

260 White Paper, note 1 above, p. 476 ('Nowhere, however, does the OECD Report suggest that the profits of the related enterprises are irrelevant to this determination'). Ibid.

261 Prop. Treas. Reg. s. 1.482-2(d)(4)(iii), 57 Fed. Reg. 3571, 3581 (30 January 1992).

262 Prop. Treas. Reg. s. 1.482-2(d)(4)(iii), 57 Fed. Reg. 3571, 3581 (30 January 1992).

${ }^{263}$ Prop. Treas. Reg. s. 1.482-2(e)(1)(ii), 57 Fed. Reg. 3571, 3585 (30 January 1992).
} 
If the results of any such method did not fall within the CPI, the transfer price was not considered 'arm's length.' ${ }^{264}$ The CPI method thus fell squarely within the definition of a 'global' or formulary method under the OECD Report, since it disregarded the transaction between the related parties altogether and substituted a transaction based on an analysis of the profits of third parties. ${ }^{265}$ While the CPI method did rely on comparables (unlike the BALRM with profit split, which the proposed regulations rejected), the standard of comparison used was so loose that our trading partners refused to consider it an 'arm's length' method. ${ }^{266}$

The proposed regulations thus marked a further step in the decline and fall of the traditional ALS based on comparables for the majority of section 482 cases. They would have also likely led to increased double taxation in the absence of agreements with our trading partners. This alone would not necessarily have been enough to condemn them. The proposed regulations, however, were also incompatible with the legislative history of the 1986 amendments (on which they relied for authority), which clearly states 'industry norms' should not be the basis for determining transfer prices. ${ }^{267}$ More importantly, as many commentators have pointed out, the proposed regulations suffered from other flaws as well. First, they were incredibly complex, requiring the application of statistical methods far beyond the understanding of most tax directors of even the largest corporations. This could have forced taxpayers to devote resources to employing economists and statisticians, rather than in more productive ways. Second, the proposed regulations relied on the ability of taxpayers to obtain information regarding the profitability of their competitors, which was unobtainable without breaching antitrust laws. ${ }^{268}$ Third, these regulations were unlikely to

264 Prop. Treas. Reg. s. 1.482-2(f)(1), 57 Fed. Reg. 3571, 3586 (30 January 1992).

${ }^{265}$ OECD Report, note 230 above, p. 19. The effect of the arm's length approach advocated by the OECD Report is 'to recognize the actual transactions as the starting point for tax assessment and not, in other than exceptional cases, to substitute other transactions for them'. Ibid.

${ }^{266}$ For an analysis of the reactions of trading partners, see 'International Chamber of Commerce Opposing Proposed Transfer Pricing Rules, 69 Daily Tax Rep. (BNA), 9 April 1992, G7; 'Proposed Transfer Pricing Regulations Could Spark Tax War, Experts Say', 115 Daily Tax Rep. (BNA), 15 June 1992, G1. See also 'U.S. Trading Partners Respond Favorably to Proposed Section 482 Regs' 95 Tax Notes Today, 11 March 1992, 55-17 (a somewhat misleading title in light of the reactions actually reported).

267 See H.R. Rep. No. 426 at 425.

268 'International Chamber of Commerce Opposing Proposed Transfer Pricing Rules', note 266 above. 
lead to any significant reduction in litigation, given the many subjective decisions involved in their application (e.g., the selection of the tested party) and the many undefined terms (e.g., 'material') that they include. Finally, the proposed regulations were totally useless as a planning tool for taxpayers, because in order to construct the CPI, they required a clairvoyant knowledge of actual future results. ${ }^{269}$

In light of this uniformly negative reaction, the IRS rapidly realised a different direction had to be taken. ${ }^{270}$ The result was the current temporary and final regulations which, on their face, appear to signal a substantial retreat by the IRS and a reaffirmation of the viability of the ALS. These appearances are, however, misleading. Closer examination reveals the temporary and final regulations will probably ensure the CPI (renamed the comparable profit method, or CPM) will be the method applied in the majority of disputed cases by the IRS to judge whether the transfer price should be adjusted, while in other cases a profit split method similar to BALRM, which does not rely on comparables at all, will be used. ${ }^{271}$

The temporary regulations, like the proposed regulations, began with the required lip service to the ALS, and omitted the modifications to the ALS that attracted criticism in the proposed regulations. ${ }^{272}$

See generally New York State Bar Assoc. Tax Section, Comments on Proposed Section 482 and Cost Sharing Regulations, 9 September 1992; D. Kevin Dolan, 'Proposed Transfer Pricing and Cost Sharing Regulations' (1992) 21 Tax Mgmt Int'l J 171; Elizabeth King, 'The Section 482 White Paper and the Proposed Regulations: A Comparison of Key Provisions' (1992) 4 Tax Notes Int'l 331, 334; Steven P. Hannes, 'An Examination of the New U.S. Transfer Pricing Proposals' (1992) 4 Tax Notes Int'l 281, 282; James P. Fuller and Ernest F. Aud, Jr, 'The Proposed Section 482 Regulations' (1992) 4 Tax Notes Int'l 599, 600. 'Service Promises Section 482 Review, Leniency Administrating Payroll Tax Rules' 92 Tax Notes Today, 3 September 1992, 180-1.

${ }^{271}$ For analyses of the temporary regulations see J. P. Fuller and E. F. Aud, Jr, 'The New Temporary and Proposed Section 482 Regulations: A Wolf in Sheep's Clothing?' (1993) 6 Tax Notes Int'l 525; S. P. Hannes, 'An Evaluation of IRS's 1993 Transfer Pricing and Related Penalty Proposals: Round Three' (1993) 6 Tax Notes Int'l 397; V. Zonana, Section 482: The 1993 Regulations - Once More, With Feeling!, Tax Club Paper (9 February 1993).

272 Temp. Treas. Reg. s. 1.482-1T(b)(1) (1993); Treas. Reg. ss. 1.482-1(b)(1)-(2) (emphasising 'arm's length results'). Compare with Prop. Treas. Reg. s. 1.482-1(b)(1), 57 Fed. Reg. 3571, 3578 (30 January 1992), which subjected the ALS to a 'sound business judgment on the basis of reasonable levels of experience' test, the 'reasonableness' test of Frank v. International Canadian Corp., 308 F.2d 520, 528-529 (9th cir. 1962), which had been rejected by the Service since 1935 . See notes $43-7$ above and accompanying text. 
However, the temporary regulations also subjected the ALS to a 'best method rule', which is retained in the final regulations, and will be an exception that swallows the traditional ALS. The best method rule (BMR) states that when the taxpayer and the Service disagree about the pricing methods to be used in reaching ALS results, the method to be used is the one that provides the 'most accurate determination' of the arm's length result. ${ }^{273}$ The factors to be weighed when choosing the method under BMR are the completeness and accuracy of the data, the degree of comparability with uncontrolled transactions, the number, magnitude and accuracy of adjustments, and whether the result agrees with any other method. ${ }^{274}$

How will the BMR be applied in practice? The answer was provided in the examples given in the temporary regulations. The first example involves a non-controversial case where the taxpayer is able to provide a comparable CUP method that fits the transaction 'with a small number of minor adjustments. ${ }^{275}$ In this case, the BMR will allow the CUP method to overcome the resale price method proposed by the IRS. ${ }^{276}$ This first example presupposed an exact comparable exists, but, as the cases surveyed above indicate, no such comparable can be found in the vast majority of real-life situations involving a dispute between the Service and the taxpayer. In such a case, the second example comes into play. Here, the taxpayer argues for CUP with 'several adjustments' which are not major ones while the Service argues for the resale price method. The CPM method, which is equivalent to CPI, reaches results that are consistent with resale price; therefore, the example indicates the similar results achieved by the resale price method and the CPM overcome the taxpayer's comparable. ${ }^{277}$

As Fuller and Aud suggest, this example 'borders on the 1992 proposed regulations' requirement that the resale price method be tested and pass muster under the CPI.278 In effect, whenever the IRS

${ }^{273}$ Temp. Treas. Reg. s. 1.482-1T(b)(2)(iii) (1994); Treas. Reg. s. 1.482-1(c).

${ }^{274}$ Ibid.

${ }^{275}$ Temp. Treas. Reg. s. 1.482-1T(b)(2)(iii)(C), Example 1 (1993); cf. Treas. Reg. s. 1.482-8, Example 1.

276 Ibid. $\quad{ }^{277}$ Temp. Treas. Reg. s. 1.482-1T(b)(2)(iii)(C), Example 2 (1993).

278 Fuller and Aud, 'The New Temporary and Proposed Section 482 Regulations', note 271 above, 527. The example was dropped from the final regulations, but under the examples that were included, the CUP (and CUT for intangibles) apply only where identical comparables are found, so that the CPM will apply in most cases under the BMR. See Treas. Reg. s. 1.482-8. 
and the taxpayer disagree about the pricing method, which is essentially in every case in which the application of the ALS is important, the two competing methods have to be tested under the CPM. Although the temporary regulations refrained from mandating, they strongly suggested that the method that is consistent with the CPM should prevail. Thus, in the temporary regulations, as in the proposed regulations, unless the taxpayer can find an exact comparable or one that requires only minor adjustments, the CPM will be used to 'trump' any taxpayer method (including the CUP) that is inconsistent with its results. ${ }^{279}$

The conclusion that the temporary regulations represent only a tactical retreat by the IRS from the proposed regulations' emphasis on the CPI is bolstered by examining the precise methods used for tangible and intangible transfers. For tangible property, the temporary regulations permit the use of CUP, resale price, cost plus, CPM or 'other methods.'280 While CUP 'ordinarily will provide the most accurate measure of an arm's length price for the transfer of tangible property, ${ }^{281}$ the standard of comparability is that the property and the circumstances must be 'substantially the same, ${ }^{282}$ and a 'reasonable number of adjustments' for 'minor' differences can be made only 'if such differences have a definite and reasonably ascertainable effect on prices or profits. ${ }^{283}$ This level of comparability will rarely be found.

The other permitted methods (resale price and cost plus) do not require such a high standard of comparability; ${ }^{284}$ but if the taxpayer disagrees with the Service on their application, the disagreement is likely to be resolved by resorting to the CPM. Thus, in practice, the temporary regulations have the same structure as the proposed regulations because the CPM still 'trumps' the competing method used by the taxpayer in the

279 See Prop. Treas. Reg. s. 1.482, 58 Fed. Reg. 5263, 5265 (Intro. to Temp. Treas. Reg.) (21 January 1993) (noting the criticism that 'elevating CPM to such a high level of priority was inconsistent with' the ALS); see also J. Turro, 'An Interview with U.S. Treasury International Tax Counsel Jim Mogle (1993) 6 Tax Notes Int'l 303 (the International Tax Counsel accepts the criticism).

280 Temp. Treas. Reg. s. 1.482-3T(a)(1)-(5) (1993).

281 Temp. Treas. Reg. s. 1.482-3T(b)(1) (1993).

282 Temp. Treas. Reg. s. $1.482-3 \mathrm{~T}$ (b)(2)(i) (1993).

283 Temp. Treas. Reg. s. 1.482-1T(c)(2)(ii) (1993); cf. Treas. Reg. s. 1.482-3(b)(2)(II).

284 Temp. Treas. Reg. ss. $1.482-3 \mathrm{~T}(\mathrm{c})(3)(\mathrm{i}), 1.482-3 \mathrm{~T}(\mathrm{~d})(3)(\mathrm{i})$ (1993) (both stating 'close physical similarity of the property involved in the controlled and uncontrolled transactions is not ordinarily necessary' for the resale price and cost plus methods, respectively). 
absence of an exact comparable. ${ }^{285}$ This pattern is repeated with even greater clarity in the intangibles portion of the temporary regulations. The only method that can be used other than the CPM is the 'comparable uncontrolled transaction' (CUT) method which requires that the comparable intangible be of the same class, relate to the same type of products, processes or know-how, and have 'substantially the same profit potential' as the transfer at issue. ${ }^{286}$ The last requirement is likely to prove impossible to meet because almost by definition intangibles licensed to unrelated parties will not have the same profit potential as those retained within the related group. ${ }^{287}$ In the absence of such a precise uncontrolled comparable, the taxpayer is practically required to use CPM. ${ }^{288}$

CPM itself is essentially the same as CPI in the proposed regulations, but in some ways it deviates even further from the traditional ALS. CPM is applied to the 'tested party', measured by profit level indicators derived from uncontrolled taxpayers that engage in 'similar business activities. $^{289}$ The definition of 'similar business activities' is extremely broad. The uncontrolled taxpayers need be only 'broadly similar', while 'significant product diversity and some functional diversity between the controlled and uncontrolled transactions is acceptable. ${ }^{290}$ If this liberal standard is met, CPM will be applied by constructing an 'arm's length range' from the operating profits of the 'comparables'. CPM can be applied even if the 'broadly similar' standard is not met; in that case, the 'arm's length range' will 'ordinarily' consist of the interquartile range

285 Temp. Treas. Reg. ss. 1.482-3T(c)-(d) (1993); cf. Treas. Reg. ss. 1.482-3(c)-(d). The taxpayer is unlikely to use 'other methods' despite the permission given in the temporary regulations, Temp. Treas. Reg. s. 1.482-3T(e) (1993), and the final regulations, Treas. Reg. s. 1.482-3(e), because such methods do not satisfy the 'reasonable belief' standard of the attendant penalty provisions. See Treas. Reg. s. 1.6662-5(j)(5)(iii), which subject the taxpayer to draconian penalties of 20 or 40 per cent of the underpayment. IRC ss. 6662(a), (h)(1).

${ }^{286}$ Temp. Treas. Reg. s. 1.482-4T(c) (1993); cf. Treas. Reg. s. 1.482-4(c).

287 Temp. Treas. Reg. s. 1.482-4T(c)(2)(ii)(A) (1993); cf. Treas. Reg. section 1.482-4(c)(2) (iii). In addition, the comparable transfer must meet a stringent list of 'comparable circumstances'. Temp. Treas. Reg. s. 1.482-4T(c)(2)(ii)(B) (1993); cf. Treas. Reg. s. $1.482-4(\mathrm{c})(2)(\mathrm{iii})(\mathrm{B})$.

288 Theoretically, the taxpayer can use 'other methods', but once again, their use is constrained by the risk of penalties. IRC s. 6662. See Fuller and Aud, 'The New Temporary and Proposed Section 482 Regulations', note 271 above, at 540 ('The effect is all too clear: since CUT is very narrow and "other" methods may not be penalty proof, the regulations have a strong bias towards the use of $\mathrm{CPM}^{\text {') }}$.

289 Temp. Treas. Reg. s. 1.482-5T(c)(1) (1993); cf. Treas. Reg. s. 1.482-5(c).

290 Temp. Treas. Reg. s. 1.482-5T(c)(1) (1993); cf. Treas. Reg. s. 1.482-5(c). 
from the 25th to the 75th percentile of the constructive operating profits derived from the profit level indicators of the 'comparable' parties. ${ }^{291}$

The pretence that CPM is somehow consistent with the traditional ALS because it uses some form of comparables is so thin in this case that it is hard to accept it with a straight face. The 'arm's length' result under this rule must be constructed by using the profits of other parties that are not even 'broadly similar' to the related taxpayers under an extremely liberal standard of similarity. There is no question this use of the CPM is inconsistent with the 1979 OECD Report, which, as we have seen, only allows 'some regard to the total profits of the relevant [multinational enterprise] . . a as a check on the assessment of the arm's length price. ${ }^{292}$ The temporary regulations thus represent a return to the basic White Paper position of paying lip service to the traditional ALS while, in effect, substituting a much broader and more flexible definition of 'arm's length' for it. In practice, whenever a disagreement arises between the taxpayer and the IRS and there is no exact comparable - which is the vast majority of the cases in which the application of the ALS is significant the winning method is the CPM, according to the Service. The CPM hardly attempts to masquerade as an ALS method.

The final regulations, issued in July 1994, are 'generally consistent' with the temporary regulations, and follow the same 'basic policies. ${ }^{293}$ Once again, the emphasis is on arm's length results. A controlled transaction meets the ALS 'if the results of the transaction are consistent with the results that would have been realized if uncontrolled taxpayers had engaged in the same transaction under the same circumstances (arm's length result). ${ }^{294}$ The best method rule (BMR), employed in deciding which method the taxpayer and the IRS should follow, states that the method used must be the one which 'provides the most reliable measure of an arm's length result. ${ }^{295}$ ments, 5 July 1994, 117. On the final regulations, see G. N. Carlson et al., "The Final Transfer Pricing Regulations: The More Things Change, The More They Stay the Same', Tax Notes Today, 29 July 1994; S. P. Hannes, 'IRS 1994 Transfer Pricing Rules Reward Planning and Documentation, Increase Penalty Risks', Tax Notes Today, 1 August 1994.

294 Treas. Reg. s. 1.482-1(b)(1).

Temp Treas. Reg. s. 1.482-5T(d)(2)(ii) (1993); cf. Treas. Reg. s. 1.482-1(e)(2).

OECD Report, note 230 above, p. 15. Predictably, our trading partners objected that the temporary regulations 'are still not fully consistent with the internationally accepted arm's length standard'. 'Korean Finance Ministry Comments on Transfer Pricing Regs', Tax Notes Today, 31 August 1993. See also 'German Industry Rep Takes Aim at Proposed Regs', Tax Notes Today, 5 August 1993; 'Keidanren Urges IRS to Take Another Look at Proposed Regs', Tax Notes Today, 29 July 1993.

295 Treas. Reg. s. 1.482-1(c)(1). 
Thus, the redefinition of the ALS has been completed. A need for the use of any comparable no longer exists; if a method reaches the same result as what would have been reached on an arm's length basis without resort to comparables, it is compatible with the ALS and should be applied.

The main difference between the final and temporary regulations is the increased flexibility that the final regulations afford both the taxpayer and the Service. Instead of relying on the superiority of the CPM, the final regulations emphasise the equal status of all the specified methods, leaving the taxpayer and the Service free to argue which provides the best arm's length results under the BMR. As one commentator has noted, this feature of the final regulations provides taxpayers with "flexibility that may approach that allowed under the 1968 regulations. ${ }^{296}$ However, this is hardly a great compliment, given the fate of the 1968 regulations in the courts. As the architect of the 1993 temporary regulations has stated, this may well create greater controversy and litigation in the future, without an end in sight. ${ }^{297}$ In practice, it still remains likely, in the view of many commentators, that the Service's field agents will employ the CPM as their method of choice, ${ }^{298}$ while taxpayers will prefer other methods. The resulting dispute concerning which method really is the best estimate of arm's length results will arrive in the courts once again.

The most significant innovation of the final regulations is the elevation of profit split to a status equal with all other methods of reaching an arm's length result. The two-level analysis described below may be performed in cases where either party owns significant intangibles resulting in a residual profit higher than the profit resulting from the regular functions of the parties. First, the profits resulting from the standard functions performed by the parties are allocated on the basis of market comparables; and second, the residual profit is split according to which party bore the costs of developing the intangibles (and not which party formally owns the intangible). ${ }^{299}$ It is likely in many of the cases reaching litigation, that the parties will have significant high-profit intangibles; therefore, the profit

296 Carlson et al., 'The Final Transfer Pricing Regulations', note 293 above, XIII.

297 J. Turro, 'Mogle Comments on Finalized Transfer Pricing Regulations', Tax Notes Today, 6 July 1994.

298 Hannes, 'IRS 1994 Transfer Pricing Rules', note 293 above; see also 'Foreign Tax Officials Discuss Final Transfer Pricing Regs', Tax Notes Today, 30 September 1994 (expressing foreign concerns regarding the United States' use of the CPM under the 1994 regulations).

299 Treas. Reg. s. 1.482-6. 
split method will be the one applied under the BMR. ${ }^{300}$ This 'residual profit split' method, however, is clearly not within the traditional ALS because it does not rely on comparables in making the crucial determination about splitting the residual. As the Treasury observed in its release accompanying the final regulations, the United States for many years has been reluctant to permit wide use of profit split methods because they do not refer solely to results of transactions between unrelated parties in determining an arm's length result. To the extent that they do not rely on such results they may be considered to be inconsistent with the arm's length standard. There are, however, cases in which it is impossible to locate adequate data to reliably apply one of the other methods. In such a case a profit split may be the best available method. ${ }^{301}$

The adoption of the profit split method in the final regulations marks the culmination of the trend we have observed since 1972: the fall of the traditional comparable-based ALS and its replacement by an expanded definition of 'arm's length', which includes any method reaching arm's length results. Once the conceptual step to an expanded arm's length definition is taken, however, no logical barrier exists to accepting any method which leads to arm's length results, including formulary methods. The actions needed to take this further step are the topic of the final section of this chapter.

\section{$3.6 \quad 1994-2010$}

Sixteen years have passed since the new transfer pricing regulations were issued in 1994. In general, these years have been marked by the unwillingness of either the taxpayers or the IRS to challenge directly the application of the new regulations. Instead, most of the activity has been either in the APA program, which has grown to over 800 APAs concluded by 2010, in the administrative appeals process, or relating to peripheral though important issues like cost sharing. As a result, it is hard to tell what impact the new regulations have had on transfer pricing litigation.

The transfer pricing cases litigated since 1995 fall into two periods. From 1995 to 2000 there were several cases litigated, all of which still fell under the old regulations, and most of which were taxpayer victories.

300 Commentators have noted that the profit split method based on comparables is unlikely to be used. See, e.g., Carlson et al., 'The Final Transfer Pricing Regulations', note 293 above, VII.

301 Treasury Release on Final Section 482 Regulations, Tax Notes Today, 6 July 1994. 
Then there was a hiatus, with no reported cases between 2001 and 2005, followed by the first important decision on cost sharing in 2005. This was followed by a lull, but there were another two important decisions on cost sharing in 2009 , both ultimately won by the taxpayer.

The cases litigated in the period between 1995 and 2000 were under the old regulations and continued the trend of taxpayer victories in the transfer pricing area, although some split the difference between the IRS and the taxpayer. In Altama Delta Corp., the Tax Court applied the cost plus method under the 1968 regulations to transfer prices charged by a Puerto Rico-based corporation electing the cost sharing method under section 936 which sold combat boot uppers to its US parent corporation, which manufactured and sold finished combat boots under a Department of Defense contract. ${ }^{302}$ The IRS attempted to limit the subsidiary to either a 15 per cent mark-up on its non-material costs or to a 7.5 per cent mark-up on all costs. The court rejected the government's argument on the grounds that the government's purported comparables were general footwear manufacturers, whereas the taxpayer was in the combat boot industry, which enjoyed higher profits in the years in question. The court also ruled that the government's attempt to apply operating profit rather than gross profit margins was unreasonable and was not a valid application of the cost plus method. The court generally accepted the taxpayer's application to the subsidiary of gross profit margins earned by others in the combat boot industry, but it limited the gross margin because the parent faced higher risks than the subsidiary.

Inverworld, Inc. v. Commissioner is generally considered an IRS victory because the case involved other issues relating to the US subsidiary of a Caymans corporation controlled by Mexican principals. ${ }^{303}$ However, the case also had a transfer pricing issue, and the Tax Court held that the IRS' method of allocating income to the US subsidiary was arbitrary and unreasonable and that the correct amount should be based on arm's length fees charged by the subsidiary to its clients.

DHL Corp. v. Commissioner was an important case involving intangibles. The taxpayer in 1992 sold to DHLI, its foreign affiliate, the worldwide rights to its trademark for US $\$ 20$ million. At the same time, DHL sold 57.5 per cent of DHLI to three unrelated investors. ${ }^{304}$

302 Altama Delta Corp. v. Commissioner, 104 T.C. 424 (1995).

303 Inverworld, Inc. v. Commissioner, 71 T.C.M. 3231 (1996) and 73 T.C.M. 2777 (1997).

304 DHL Corp. v. Commissioner, 76 T.C.M. 1122 (1998), aff'd in part and rev's in part, 285

F.3d 12109 th Cir. 2002. 
The IRS argued that the arm's length price should have been US $\$ 300$ million, while the taxpayer valued it at US $\$ 50$ million. The Tax Court rejected both valuation estimates, and concluded that the value of the trademark was US $\$ 150$ million, or 50 per cent of the IRS valuation, and that US $\$ 50$ million of that was associated with US rights and US $\$ 100$ million with foreign rights. The Ninth Circuit affirmed on the valuation of the US rights, but rejected any adjustment for foreign rights because DHLI and not DHL was the owner of such rights under the 1968 regulations, since it incurred most of the expenses in developing such rights. Thus, the end-result of a US $\$ 50$ million adjustment was the same as the taxpayer's position and the case should be viewed as a significant taxpayer victory in the important area of intangible valuation.

GAC Produce Co. Inc. illustrates that the IRS can win transfer pricing cases against small and medium taxpayers that do not have the litigating resources enjoyed by major multinationals. ${ }^{305}$ The case involved a corporate distributor of fresh produce and its controlled entities in Mexico, and the Tax Court held that the commissions received by the distributor for marketing services were below arm's length because they did not even cover its costs. The taxpayer position lost because it was extreme, and it is doubtful the case can be relied upon as evidence of an improvement in the IRS' litigation record.

In UPS v. Commissioner the taxpayer transferred its profits from excess valuation charges, which are premiums paid by customers for replacement of packages lost or damaged in shipping, to a Bermuda affiliate. ${ }^{306}$ The Tax Court rejected the transfer as a sham, because while the nominal transfer was to an unrelated party the ultimate risk and profit was to the related party, OPL. However, the Court of Appeals reversed, resulting in another significant taxpayer victory in the area of intangibles. The main rationale for the Court of Appeals decision was that the charges to unrelated customers were arm's length, but this does not explain why the significant profits should be deemed earned by OPL, rather than the taxpayer.

In Compaq v. Commissioner the taxpayer purchased about 50 per cent of its printed circuit assemblies from a Singapore subsidiary. ${ }^{307}$ The taxpayer set its prices on a modified cost plus basis, using US standard

305 GAC Produce Co., Inc. v. Commissioner, 77 T.C.M. 1890 (1999).

306 United Parcel Service v. Commissioner, 78 T.C.M. 262 (1999), rev'd, 11th Cir.

307 Compaq Computer Corp. v. Commissioner, 78 T.C.M. 20 (1999). 
costs which were less than Singapore standard costs. The IRS rejected this method, but the Tax Court approved the taxpayer's position, and concluded that the notice of deficiency was arbitrary and capricious and that the prices should be upheld under CUP. The court accepted the taxpayer's allocation of location savings to the subsidiary and also declined to adjust the price for volume discounts because these were not required under the 1968 regulations.

After Compaq there are no final decisions in transfer pricing cases until 2005, when the first decision on cost sharing came down and was another major taxpayer victory. Cost sharing grew out of the super royalty rule that was enacted in 1986 to prevent royalty-free transfers of intangibles to low tax subsidiaries. Under cost sharing, the taxpayer and its foreign affiliate can enter into an agreement to share the costs of developing an intangible in a prescribed ratio, such as 20 to 80 per cent. The low tax affiliate then pays for its share of the costs of development, 80 per cent in this case, and as a result can book 80 per cent of the resulting profit without being subject to IRS challenge or to the super royalty rule. Importantly, no research and development needs to actually take place in the low tax affiliate, which just has to pay for the costs with funds contributed by the parent. If the costs are US $\$ 1$ million and the profit is US $\$ 1$ billion, a not unreasonable assumption for pharmaceutical patents, the low tax affiliate can shelter US $\$ 800$ million from tax at a cost of US $\$ 800,000 .^{308}$

The rationale behind the rule was that if the research and development is unsuccessful, the taxpayer gives up on the deduction of the costs allocated to the low tax affiliate, since it is a foreign source deduction. But it seems very generous to allow US $\$ 800$ million to escape from tax at a potential risk of a US $\$ 800,000$ deduction. In addition, taxpayers avoided even that risk by entering into the agreement only after the value of the research and development was already established, although then they had to argue with the IRS on the value of the 'buy in' payment the affiliate had to make for the established value of the intangible.

The issue in Xilinx v. Commissioner was whether in calculating the cost to be included in a cost sharing agreement, the taxpayer had to include the cost of exercising stock options granted to employees who were performing the R\&D. ${ }^{309}$ The Tax Court held that because cost sharing is covered by the ALS, the cost of options should not be included because 
unrelated parties would not have been willing to share the cost of the options. This case is a very pro-taxpayer result because the deduction of the option exercise frequently wipes out the US tax liability of high tech companies, so that as a result most of the profit from an intangible can remain offshore while the portion allocated to the United States under the agreement is protected from tax by deducting the option exercise costs. The case once again illustrates how unrealistic it is to rely on the ALS because these agreements are usually not entered into between unrelated parties, and thus the cost sharing issue does not arise.

On appeal, the US Court of Appeals for the Ninth Circuit initially reversed Xilinx. ${ }^{310}$ By a two to one majority, the panel held that costs of employee stock options must be included in the pool of costs subject to a tax sharing agreement. However, the same panel later reversed itself and held for the taxpayer.

The Tax Court decided Xilinx on the ground that unrelated parties dealing with each other at arm's length would not have shared the cost of employee stock options, and therefore the ALS requires that these costs not be shared under a cost sharing agreement either. ${ }^{311}$ The Court of Appeals explicitly accepted this factual finding and even went further in explaining why unrelated parties would never share the costs of such options. Nevertheless, the majority decided (over a vigorous dissent by Judge Noonan) to require inclusion of the stock option costs in the sharing pool, ${ }^{312}$

The issue in Xilinx was whether to include the cost of employee stock options in the pool of costs to be shared under a cost sharing agreement with Xilinx's Irish subsidiary. In general, the more costs need to be shared, the less valuable is the cost sharing agreement to the taxpayer, because costs allocated to the Irish subsidiary cannot be deducted in the United States. Many high tech companies are able to eliminate their US tax liability by deducting the cost of stock options, while locating their foreign profits in low tax jurisdictions such as Ireland.

The Tax Court and the dissent argued that because the costs of the options would not be shared by unrelated parties, under the ALS they cannot be included in the pool of costs to be shared under the cost sharing agreement. They pointed out that Treas. Reg. 1.482-1(b)(1) requires that 'the standard to be applied in every case is that of a taxpayer dealing at arm's length with an uncontrolled taxpayer', and that of the US-Ireland tax treaties requires applying the ALS to transfer pricing

${ }^{310}$ Xilinx, Inc. v. Commissioner, No. 06-74246, 2009 Us App. LEXIS 11118 (9th Cir. 2009).

311 Xilinx, Inc. v. Commissioner, 125 T.C. 37 (2005). ${ }_{312}^{3}$ Ibid. 
cases. Judge Noonan in dissent argued that the ALS is essential to the purpose of the transfer pricing regulations, which is 'parity between taxpayers in uncontrolled transactions and taxpayers in controlled transactions. The regulations are not to be construed to stultify that purpose. If the [ALS] is trumped by [the cost sharing regulations] the purpose of the statute is frustrated. ${ }^{313}$

However, the majority held that the ALS was not the purpose of IRC 482: 'Significantly, achieving an arm's length result is not itself the regulatory regime's goal; rather, its purpose is to prevent tax evasion by ensuring taxpayers accurately reflect taxable income attributable to controlled transactions. ${ }^{314}$ It then held that the language of Treas. Reg. 1.482-1(b) (1), incorporating the ALS, is irreconcilable with the language of Treas. Reg. 1.482-7(d)(1), which required the sharing of 'all of the costs' related to developing the shared intangible. The conflict arises because unrelated taxpayers do not share stock options costs because (i) they are hard to value because no cash outlay is involved; (ii) sharing them in an unrelated joint venture would create an incentive to minimise the value of the joint venture to reduce the cost of the options; and (iii) sharing the costs reduces the deductions available to the taxpayer. ${ }^{315}$ For these reasons, there will be no comparables in which the costs are shared, but the court nevertheless held that the 'all of the costs' requirement governs because it is the more specific regulation. Finally, the court rejected the challenge based on the US--Ireland tax treaty because of the savings clause, which is found in every US tax treaty and states that the treaty cannot affect the ability of the United States to tax its own residents, such as Xilinx.

I believe that given the history of IRC 482 and the cost sharing regulations, the majority were clearly right, albeit not quite for the reason they give (as the dissent correctly notes, it is hard to put too much weight on canons of construction such as the one the majority relied on, i.e., that the specific trumps the general). First, IRC 482 predates the ALS by at least a decade, so that it cannot be said that the ALS is 'the purpose' of IRC $482 .{ }^{316}$ Rather, as the majority correctly argued, the purpose of IRC 482 is to accurately reflect the taxpayer's income and prevent tax evasion, and the ALS is only a means to that end

313 Xilinx, Inc. v. Commissioner, Court of Appeals decision at 6180.

314 Ibid. 6167. ${ }^{315}$ Ibid. 6176.

316 R. S. Avi-Yonah, The Rise and Fall of Arm's Length: A Study in the Evolution of US International Taxation, University of Michigan Law and Economics, Olin Working Paper No 07-017 (2007). 
(which was not really given meaning until 1968, over four decades after the language of IRC 482 was enacted).

Second, there is a good reason why cost sharing cannot be reconciled with the ALS: cost sharing grew out of the super royalty rule, which was explicitly not based on the ALS. Thus, the majority were quite correct in viewing cost sharing as a distinct regime that is not subject to the ALS. If unrelated parties do not share costs that related parties do, that means that cost sharing between related parties cannot be governed by the ALS, and that the ALS is irrelevant to this area of transfer pricing law. That was the insight of Congress when it enacted the super royalty rule in 1986, and the same insight should be applied to cost sharing.

Third, the majority were also correct in rejecting the challenge posed by the US-Ireland treaty. However, their reasoning has interesting implications which they do not seem to appreciate. The majority stated that 'Xilinx is not a foreign entity, so applying $1.482-7(\mathrm{~d})(1)$ to it does not violate the treaty, even if the regulations' all costs requirement is at odds with the treaty's arm's length standard. ${ }^{317}$ But this point applies to all transfer pricing cases, not just to those involving a US parent, because Xilinx also involved a foreign entity (the Irish subsidiary). If the savings clause is read to enable the IRS to apply non-ALS methods to Xilinx, it can also apply them to US subsidiaries of foreign parents, because those are also US resident corporations. In that case the only cases where the ALS applies under a treaty would be to US branches of foreign entities, as the courts held (incorrectly) in Natwest. ${ }^{318}$

Unfortunately, Xilinx was reversed by the same panel, because the taxpayer and its allies were able to persuade the panel that the ALS is a binding standard that must be complied with in all cases. The same result was reached in Veritas, another cost sharing case in which the court rejected the method used by the IRS to calculate a buy-in payment for an intangible, preferring to adopt the taxpayer's comparable uncontrolled transaction method despite clear economic differences. ${ }^{319}$ This case is important because taxpayers frequently wait until they know that an intangible is valuable before they begin sharing costs with a foreign

Xilinx, note 311 above, 6171.

318 National Westminster Bank v. United States, 512 F.3d 1347 (Fed. Cir. 2008) (holding ALS in Chapter 7 of the United States-United Kingdom treaty trumps the interest allocations regulations). In my opinion this case was wrongly decided because of the long tradition of applying formulas to reach arm's length results, which is the only requirement under Art. 7 (see OECD Model, Art. 7(4)).

319 Veritas Software Corp. v. Commissioner, 133 T.C. No. 14 (2009). 
affiliate, so as not to risk losing the deduction for some of the costs if the $\mathrm{R} \& \mathrm{D}$ is unsuccessful. If taxpayers can minimise buy-in payments, there is no risk in entering into cost sharing agreements.

The IRS has attempted to deal with some of the issues in these cases by issuing new regulations. It now has issued regulations on transfer pricing related to both services and intangibles, which are in general similar to the 1994 regulations, with some modifications. It has also recently adopted new cost sharing regulations that would limit the advantage of the method by requiring that if the low tax affiliate only contributes cash, it only gets a normal return on the cash, with the rest of the profit allocated to the parent. However, in the final version these regulations were relaxed and the results in Xilinx and Veritas make the method more attractive. The Obama administration has proposed to limit cost sharing and other intangible transfer methods, but it is unclear whether Congress will act.

Thus, the litigation record since 1994 has not in general favoured the IRS much more than the pre-1994 record, although none of these cases except Xilinx and Veritas were litigated under the new regulations. Some taxpayers are entering APAs, but these cover only a small part of the overall transfer pricing universe. Instead, most taxpayers appear to be taking a wait and see attitude until the first major case under the new regulations is decided.

For a while, this case seemed likely to be Glaxo. Glaxo involved the proper allocation of the profit from selling the antacid drug Zantac in the United States between the UK parent, Glaxo-Wellcome, which did the research and development and production, and its US affiliate, which did the distribution. The IRS argued that 50 per cent of the profit should be allocated to distribution, while the United Kingdom claimed most of the profit relates to $\mathrm{R} \& \mathrm{D}$ and production.

If the IRS had won Glaxo, that would have helped drive reluctant taxpayers into the APA program, which is the best hope of resolving the transfer pricing mess in the absence of consensus on a formula. However, the IRS chose to settle, albeit for a hefty US $\$ 3.4$ billion (out of about US $\$ 10$ billion at stake). One can understand why, given the litigation record, but now we have to wait until the next big case.

\subsection{Conclusion}

Fundamentally, I have long believed that corporate taxation should be source-based, rather than residence-based. The reasons for this belief are that (a) corporate residence is not very meaningful, since unlike 
individuals corporations are not physically present in any country, cannot vote, and are an inappropriate subject for redistributive taxation; and that (b) source-based taxation of corporations rests on the benefits corporations receive from engaging in business activity in countries that incurred costs to enable that business activity to take place.

This argument supports the view of those who would move the United States closer to a territorial system. Territoriality has many advantages, because it eliminates the incentive not to repatriate earnings, and offers simplification potential in reducing the need for a foreign tax credit. If done properly, it is also a revenue raiser because deductions allocated to exempt foreign source income would be disallowed.

But I have also repeatedly argued against moving in the direction of territoriality in the current context, and have also supported efforts (like the current one by the Obama administration) to restrict or even repeal deferral. The reason is simple: without transfer pricing reform, territoriality will in my opinion lead to an even stronger incentive to shift profits overseas, and to further revenue losses and erosion of the US corporate tax base. ${ }^{320}$

Thus, I believe that the key to any international tax reform must be a transfer pricing overhaul. As my co-authors Kim Clausing and Michael Durst and I have argued, one possibility is to adopt a formula (which we suggested should be sales-based) to split profits left over after routine contributions by the related affiliates are accounted for. ${ }^{321}$

Such a reform can be enacted by Congress, and we have included proposed legislative language in our chapter. The original Ninth Circuit decision in Xilinx supports our position because it points out that the ALS cannot be applied in a key area of transfer pricing law.

However, our proposals have not so far persuaded opponents of formulary apportionment (FA). Instead, the advocates of the ALS point to a list of asserted deficiencies of FA, including:

1. FA is inherently arbitrary.

2. FA will produce double taxation because some countries will apply the ALS and others FA, and the FA countries will each have a different formula.

320 See R. S. Avi-Yonah, 'Comment on Yin, Reforming the Taxation of Foreign Direct Investment by US Taxpayers' (2008) 28 VA Tax Rev. 281.

321 R. S. Avi-Yonah, A. K. Clausing and M. Durst, 'Allocating Business Profits for Tax Purposes: A Proposal to Adopt a Formulary Profit Split' (2009) 9(5) Florida Tax Rev. 497-553. 
3. FA requires an impossible-to-achieve uniformity of the tax base.

4. FA violates tax treaties.

5. FA will be impossible to enact because of the opposition of the multinationals and of countries that will lose from its implementation.

I believe that there is a good answer to each of these arguments, and have in fact replied to them at length elsewhere. ${ }^{322}$ However, I also realise that my answers are unlikely to persuade FA opponents. Thus, I want to use this chapter to propose a more modest step forward: adopting FA only in the context of ALS (rather than replacing the ALS with FA).

The basic problem arises in situations where there are no good comparables. If good comparables exist, the traditional methods (CUP, cost plus and resale price) can be used, and that would end the story. But as the OECD Guidelines acknowledge, in many cases good comparables are hard to find.

The next possible alternative under the OECD Guidelines is the transactional net margin method (TNMM). However, TNMM requires a tougher comparability test than the US CPM, which is good because CPM has proven to be the most manipulable of the current methods: an informed economist working for a major accounting firm has told me he can achieve any result the client wants using CPM. CPM is also a huge source of transactional complexity, a boon to the large accounting firms, and a problem for those who cannot afford their services. But the tougher OECD TNMM comparability standard means that TNMM cannot be applied in many cases in which CPM is used in the United States.

This leaves profit split. Under profit split, comparables are used to allocate the return on routine functions. But that usually leaves a residual in place, which arises precisely because multinationals exist to earn a return that cannot be achieved in an arm's length relationship. That, as explained above, is why good comparables are hard to find.

322 Avi-Yonah, Clausing and Durst, ibid.; on the treaties point see also R. Avi-Yonah and A. K. Clausing, 'Reforming Corporate Taxation in a Global Economy: A Proposal to Adopt Formulary Apportionment' in J. Furman and J. Bordoff (eds.), Path to Prosperity: Hamilton Project Ideas on Income Security, Education, and Taxes (Brookings Institution Press, 2008) pp. 319-44. If the Xilinx court was right, however, then FA does not violate Chapter 9 of the treaties because of the savings clause. 
Thus, the key issue in current transfer pricing is how to allocate the residual under the profit split method. The US regulations assume that the residual is the result of high profit intangibles and allocate it to where such intangibles were developed. However, this method is not helpful because (a) the OECD and the rest of the world rejects it; (b) it penalises multinationals for conducting $R \& D$ in the United States; and (c) it encourages multinationals to enter into cost sharing agreements that artificially shift profits to low tax jurisdictions. In addition, as the Bausch \& Lomb court stated, if the value of the intangible results from the fact that two parties are related, that added value is distinct from where it was developed.

If the US approach is rejected, the question is how to allocate the residual. The OECD Guidelines are silent on this issue. This presents an opportunity: perhaps in this context, it should be possible to adopt a formula to allocate the residual.

One needs to realise that if there are no comparables (by definition) and the residual results from the relationship between the parties and would disappear if they were unrelated, then the ALS is meaningless and any allocation is arbitrary. Under these circumstances the key is to adopt the formula that is most likely to achieve consensus.

In the unilateral US context, my co-authors and I support a salesbased formula similar to the destination-basis formula for VAT. This choice of formula favours exports and therefore is likely to be politically popular, and it favours the United States because of our trade deficit. ${ }^{323}$ In the OECD context, I would prefer a more balanced formula with three components: payroll, tangible assets and sales.

These three components are, of course, the traditional US state FA formula. This formula has proven to be remarkably successful, since in addition to the US states, it is also the basis for the global dealing regulations in the United States and OECD, and is a leading candidate for the EU's Common Consolidated Corporate Tax Base (CCCTB) formula. I believe it makes sense because each of its elements is objective (payroll and sales are transactions with outside parties, and while tangible assets depend on valuations, there is a lot of experience with asset-based formulas, such as the US interest allocation formula). Intangibles are excluded, but in my opinion that is appropriate because (a) their value results from physical and human capital and from the market and

${ }^{323}$ Avi-Yonah and Clausing, 'Reforming Corporate Taxation in a Global Economy', note 322 above. 
those elements are included, and (b) you cannot allocate their value and trying to include them invites manipulation.

Thus, I would propose that in hard transfer pricing cases, in which no comparables can be found beyond the return on routine functions, the United States should adopt and the OECD should endorse using the traditional three factor state formula to allocate the residual under the profit split method.

I believe this proposal addresses the problems with FA outlined above:

1. While the formula is arbitrary it relates to economic reality, and any allocation is arbitrary in the absence of comparables. The current OECD Guidelines are also arbitrary in not allocating residuals.

2. It is unlikely that this outcome would lead to more double taxation than what already occurs for residuals under the ALS. If the United States allocates residuals based on location of $R \& D$ and other countries disagree, double taxation is already a threat. Disputes can be resolved using the new arbitration provision under the OECD model.

3. If the OECD accepts the residual formula under ALS, it does not violate treaties and it can be handled in the context of Chapter 9.

4. Since it is only a residual formula, the base has already been defined under ALS.

5. A balanced formula is less likely to produce consistent losers.

Xilinx presents an opportunity for reforming US international taxation. It indicates yet again that the ALS is broken beyond repair. The reasons are set out at length elsewhere, and I will not repeat them. ${ }^{324}$ I believe now is the time to reform transfer pricing, for three reasons:

1. The current debate over deferral and territoriality is unlikely to be resolved unless the Administration and Congress undertake transfer pricing reform.

2. The EU, traditionally the bulwark of the ALS, is moving toward adopting FA as part of its CCCTB project. ${ }^{325}$

${ }^{324}$ Avi-Yonah, Clausing and Durst, 'Allocating Business Profits for Tax Purposes', note 321 above.

${ }^{325}$ On CCCTB, see, e.g., J. Mintz and J. Weiner, 'Some Open Negotiation Issues Involving a Common Consolidated Corporate Tax Base in the European Union' (2008) 62 Tax L Rev. 81. 
3. Even the OECD, also a bulwark of ALS, is showing some flexibility toward adopting formulas in the context of profit split, and is about to designate profit split as a method on par with the traditional ALSbased methods. ${ }^{326}$

Thus, I believe this a propitious time for reform, and that the Administration and Congress should use the current debate over deferral and territoriality to engage in transfer pricing reform along the lines outlined above.

\section{Appendix: Questionnaire (United States)}

1. The structure of the law for solving transfer pricing disputes. What is the structure of the law of the country for solving transfer pricing disputes? For example, is the mutual agreement procedure (MAP), as regulated in the relevant tax treaty, the standard method for solving transfer pricing disputes?

The law is based on a single section of the Internal Revenue Code (section 482) which is very brief but until 1968 was the only basis for judicial decisions. In 1968 and again in 1995 there were elaborate regulatory structures added which are the basis for subsequent decisions. MAP is of limited usefulness because until recently there was no binding arbitration in US tax treaties. APAs are more useful.

2. Policy for solving transfer pricing disputes. Is there a gap between the nominal and effective method for solving transfer pricing disputes in the country? For example, has the country a strategic policy not to enforce the arm's length standard (ALS) for fear of driving foreign direct investment to other competing jurisdictions?

APAs are frequently based on methods that are not ALS (e.g., formulas). There is a lot of emphasis on profit methods. Otherwise ALS is followed.

3. The prevailing dispute resolution method. Which is the most frequent method for solving transfer pricing disputes in the country? Does it have a positive externality? For example, is the MAP the most frequent method, and if so, to what extent have successful MAPs been used as a proxy for

${ }^{326}$ See R. S. Avi-Yonah, 'Between Formulary Apportionment and the OECD Guidelines: A Proposal for Reconciliation' (2010) 2 World Tax Journal 3. 
transfer pricing case law? For instance, Procter \& Gamble (PঊG) obtained a bilateral advance pricing agreement (APA) in Europe, and it was then extended to a third (Asian) country when $P \& G$ made this request to the relevant Asian tax authorities.

Most common traditionally is litigation. After 1991 APAs become more important but a lot of taxpayers refuse to engage in them because they have been winning most of the cases after 1980 .

4. Transfer pricing case law. What is the evolution path of transfer pricing litigation in the country? For example: (i) Is transfer pricing litigation being gradually replaced by either MAPs or APAs, as regulated in the relevant tax treaties? (ii) Are foreign/local transfer pricing precedents and/ or published MAPs increasingly relevant as a source of law for solving transfer pricing disputes?

Before 1995 the most important method was litigation with taxpayers being generally very successful. Under new regulations most cases are settled in appeals and there is increasing importance of APAs but many taxpayers will not engage in the APA process. MAP is of limited usefulness.

5. Customary international law and international tax procedure. Has customary international law been applied in the country to govern the relevant methods for solving transfer pricing disputes (such as the MAP)? For example, has the OECD Manual on Effective Mutual Agreement Procedure ('OECD Manual') been deemed customary international tax law in the MAP arena for filling procedural gaps (for example, time limit for implementation of relief where treaties deviate from the OECD Model Tax Convention)?

No.

6. Procedural setting and strategic interaction. Does strategic interaction between taxpayers and tax authorities depend on the procedural setting in which they interact when trying to solve transfer pricing disputes? For example, which procedural setting in the country prompts the relevant parties to cooperate with each other the most for solving this sort of dispute, and why?

Taxpayers face a choice between going for an APA and litigating. Many taxpayers refuse to enter the APA process because they tend to prevail in 
litigation. For smaller taxpayers, however, both APAs and litigation are prohibitively expensive.

7. The future of transfer pricing disputes resolution. Which is the best available proposal in light of the interests of the country for facilitating the global resolution of transfer pricing disputes, and why?

Some combination of profit split with formulas would seem the best option because it resolves the toughest issue, which is what to do with residual profits after normal returns are accounted for. 